\title{
Bulgaristan Türklerine uygulanan zorla isim değiştirme kampanyası ve Türk basını (aralık 1984-mart 1985)
}

\section{Hasan DEMÍRHAN 1}

APA: Demirhan, H. (2019). Bulgaristan Türklerine uygulanan zorla isim değiştirme kampanyası ve Türk basını (aralık 1984-mart 1985). RumeliDE Dil ve Edebiyat Araştırmaları Dergisi, (17), 252272. DOI: $10.29000 /$ rumelide. 656753

\section{$\ddot{\mathbf{O} z}$}

Bulgaristan Komünist Parti yöneticileri 1984 yılının Aralık ayında ülkedeki toplam nüfusun yaklaşık olarak \%10’unu oluşturan Türklerin yirmi gün içerisinde isimlerini zor kullanarak değiştirmek için büyük bir kampanya başlattı. Bulgaristan hükümeti bu kampanya ile Bulgaristan'daki Türk varlığını inkar ederek, Bulgaristan’ı sadece Bulgarların yaşadığı homojen bir ulus devlete dönüştürmek istiyordu. Zorla isim değiştirme kampanyası ilk önce güney Bulgaristan'da Türklerin yoğun yaşadığı bölgelerde başlatıldı ve çok kısa bir süre sonra orta ve kuzey Bulgaristan'da yaşayan tüm Türklerin isim değişikliği tamamlandı. Kampanya sürecinde Türklere, zorla isim değiştirme uygulamasını gönüllü olarak kabul ettiklerini beyan eden dilekçeler imzalatıldı. Dilekçeleri imzalamak istemeyen ve Bulgar komünist parti yetkililerine direnen Türkler, cezaevlerine ya da toplama kamplarına sürülmekte; buralarda ağır hakaretlere ve işkencelere maruz kalmaktaydı. Türk kamuoyu Bulgaristan'da yaşananlardan ancak 1985 yılının Ocak ayında haberdar olabildi. Türk basını bu tarihten sonra Bulgaristan Türklerinin yaşadıkları haksızlıkları ve zulümleri sayfalarına taşıyarak kamuoyunun dikkatini Bulgaristan'daki Türklerin yaşadığı zulme çekmeyi başardı. Bu süreçte önceki yıllarda Türkiye'de kurulmuş olan göçmen dernekleri Bulgaristan'da yaşayan yakınlarının çektiği acıları devlet yetkililerine ve siyasi partilerin idarecilerine duyurmak için çeşitli ziyaretler yaptılar ve Türk kamuoyunun desteğinin kazanılmasında çok önemli bir rol oynadılar. Hükümet ilk günlerde Bulgaristan'da yaşananlar konusunda temkinli bir politika izledi ve konuyu kavga zeminine taşımadan, Bulgaristan hükümeti ile müzakereler yaparak çözmeyi amaçladı. Ancak Bulgaristan’ın uzlaşmaz tavrı ve ülkesindeki Türk varlığını inkara devam etmesi üzerine, Türkiye bu sorunu uluslararası platformlara taşıyarak çözmek için girişimlere başladı.

Anahtar kelimeler: Bulgaristan, baskı, isim değişikliği, Türkiye, basın.

\section{Forced name change campaign applied to Turks in Bulgaria and Turkish press (december 1984-march 1985)}

\begin{abstract}
In December 1984, Bulgarian Communist Party leaders launched a major campaign to change the names of Turks, who make up about $10 \%$ of the country's population, by force within twenty days. With this campaign, the Bulgarian government denied the Turkish presence in Bulgaria and wanted to turn Bulgaria into a homogeneous nation state inhabited only by Bulgarians. The mandatory name change campaign was first started in areas where Turks live in southern Bulgaria, and then the name change of all Turks living in central and northern Bulgaria was complete. During the campaign, the
\end{abstract}

$1 \quad$ Dr. Öğr. Üyesi, Kurklareli Üniversitesi, Fen Edebiyat Fakültesi, Tarih Bölümü (Kırklareli, Türkiye), hasandemirhan_@hotmail.com, ORCID ID: oooo-0002-5868-8317 [Makale kayt tarihi: 21.11.2019-kabul tarihi: 20.12.2019; DOI: 10.29000/rumelide.656753] 


\begin{abstract}
Turks were forced to sign a petition stating that they voluntarily accepted the practice of forced name change.d in a very short time. The Turks who refused to sign the petitions and resisted Bulgarian communist party officials were deported to prisons or concentration camps. They were subjected to severe insults and torture. The Turkish public became aware of the events in Bulgaria only in the first week of January. After that date, the Turkish press carried the injustices and atrocities suffered by the Turks in Bulgaria to their pages. In this way, they managed to draw public attention to the persecution of the Turks in Bulgaria. Immigrant associations in Turkey took advantage of every opportunity they had during this period to announce the sufferings of their relatives living in Bulgaria to the Turkish authorities and the leaders of political parties and gained public support. The Turkish government initially pursued a cautious policy on what was happening in Bulgaria and aimed to resolve the issue without any controversy by negotiating with the Bulgarian government. However, because of Bulgaria's intransigence and ongoing denial of the Turkish presence in Bulgaria, Turkey made attempts to solve this problem by moving into the international platforms.
\end{abstract}

Keywords: Bulgaria, opression, name change, Turkey, press.

\title{
Giriş
}

Bulgaristan'da yaşayan Türkler 1984 yılının Aralık ayının sonlarından 1985 yılının Şubat ayına kadar geçen yaklaşık bir aylık süre içerisinde isimlerinin zorla değiştirilmesiyle karşı karşıya kaldılar. Beş asırdır Türk ve Müslüman isimleri ile yaşadıkları topraklarda artık atalarının kendilerine verdikleri isimlerle değil, Bulgar Komünist Parti idarecilerinin kendilerine uygun gördüğü Bulgar isimleri ile yaşamaya zorlandılar. Bulgaristan'da uygulanan bu isim değişikliği, aslında dolaylı olarak bir ırk, dil ve din ayrılı̆̆ının kurnaz bir şekilde tasfiye edilmesiydi. ${ }^{2}$

Bulgar Komünist Parti yöneticilerinin 1984 yılında başlattıkları ve Bulgaristan Türklerinin asıllarının Bulgar olduğunu iddia eden Yeniden Doğuş (Soya Dönüş) Süreci (Văzroditelen protses), Bulgaristan’ın özerk bir devlet olarak ortaya çıktı̆̆ Berlin Antlaşması'ndan bu yana Bulgar milliyetçilerinin homojen bir ulus oluşturma hayalinin son aşamasıydı. Bulgaristan hükûmeti bu kampanya sonucunda ülkedeki bütün Türklerin isimlerini Bulgar isimleri ile değiştirerek Bulgaristan'daki Türk varlığının tamamen ortadan kalktığını ilan etmekteydi. Türklere uygulanan zoraki isim değiştirme uygulamalarının ardından Bulgaristan Türklerine ait olan bütün dini ve kültürel ritüellere de yasaklar getirildi.

Yeniden Doğuş (Soya Dönüş) Süreci’nin uygulanmasıyla birlikte Türklerin kamuya açlk alanlarda Türkçe konuşması yasaklandı. Türkçe konuştukları saptanan kişiler toplum huzurunu bozdukları gerekçesiyle 5 ila 20 leva arasında değişen para cezalarına çarptırıldılar. Suçun tekrarı halinde cezalar arttırıldı ve bir aylık maaş kesintisi uygulanmaya başlandı. Bu yaptırımları işten uzaklaştırmalar izledi. Kimi durumlarda iki yıla kadar hapis ve sürgün cezası uygulandı. Bulgaristan yönetimi Türkçe gazete ve dergilerin yayımlanmasını yasakladı. Bulgar radyosunun Türkçe yayınları sona erdi. Kütüphanelerde bulunan Türkçe kitaplar toplatıldı. Türkçe şarkı söyleyenler ve dinleyenler cezalandırıldı (Demirhan, 2019, s. 493). Türklerin giymiş olduğu şalvar, potur, kasket ve başörtü gibi geleneksel kıyafetler

$2 \quad$ Kişinin taşıdığ 1 isim onun dininden, dilinden ve kültüründen bir şeyler taşımakta ve onun bütün değerlerinin aslında bir sembolü anlamına gelmektedir. Bu yüzden kişilerin isim seçimleri zoraki değil hür iradeleri, fikir ve inanç hürriyetleri ile ilgilidir. Bir insanı seçtiği isimle çağrılmaktan alıkoymak; çocuklarına büyüklerinin, atalarının isimlerini vermekten men etmek; onu bütün hürriyetlerin temeli olan şahsiyet haklarından ve temel hürriyetlerden mahrum etmek anlamına gelir. Aslında zorla isim değişikliği, zorla din değişikliği, zorla dil değişikliği, zorla külttür değişikliği ve zorla rrk değişikliğidir. Böylece isim değişikliği dolaylı olarak, etnik bir grubun, bir azınlık grubunun baskı ve tehditle sona erdirilmesi anlamına gelmektedir. (Hamza Eroğlu, Milletlerarası Hukuk Açısından Bulgaristan'daki Türk Azınlığı Sorunu, Bulgaristan Türk Varlığı Bildirileri, TTK Yayınları, Ankara 1992, s.17 (15-46)) 
Forced name change campaign applied to Turks in Bulgaria and Turkish press (december 1984-march 1985) / H. Demirhan (pp. 252-272)

yasaklandı. Türkçe veya Türkçeden gelen yer isimleri değiştirildi (Lütem, 200o, s. 440). Camilere ibadet etmek için gitmek, çocukları sünnet ettirmek, kurban bayramında kurban kesmek, oruç tutmak, cenazelerin islami hususlara uygun defnedilmesi gibi ülkedeki bütün islamî uygulamalar kaldırıldı (Demirhan, 2019, s. 493-496). Bulgaristan tam anlamıyla kimliğini kaybetmek istemeyen Türkler için bir cezaevine dönüştü.

Türklere karşı başlatılan zorla isim değiştirme kampanyası Bulgaristan devleti tarafından çok gizli ve hızlı bir şekilde sonuçlandırıldı. Türk basını, komşusu Bulgaristan'da Türklere yapılan baskılardan ancak ocak ayının ilk günlerinde haberdar oldu ve yayınlarına başladı. Ancak Bulgaristan'ın bu kampanya sürecinde yabancı gazetecilerin ve diplomatların Türklerin yaşadığı bölgelere girişine izin vermeyerek yaşananların gizli kalmasını istemesi Türk ve dünya basınının işini zorlaştıran önemli bir etken oldu. Bu dönemde Türk basını Bulgaristan'dan Türkiye'deki akrabalarına gizlice gönderilmiş ve Bulgaristan'daki Türklerin durumunu anlatan mektuplar ile daha önce anavatana göç eden Bulgaristan Türklerinin kurmuş olduğu dernek yöneticilerinin beyanatlarını yayımlayarak Bulgaristan Türkünün yaşadığı ızdırabı Türk ve dünya kamuoyuna aksettirebildi. Bu çalışmada Bulgaristan'da zorla isim değiştirme kampanyası ile ilgili 1984 Ocak ayı ile 1985 Mart ayı arasında Türk basınında çıan haberler değerlendirilmiştir.

\section{Zorla isim değiştirme kampanyasının tarihsel süreci}

Bulgar milliyetçileri Bulgaristan kurulduğu andan itibaren etnik olarak Bulgar olan homojen bir ulus oluşturmayı amaçladılar. Bu amaçlarına ulaşmak için de Osmanlı Devleti’nden Bulgaristan'a miras kalan farklı ulusal azınlıkları asimile etmek için büyük bir çabaya giriştiler. Bu asimile politikalarının içerisinde zorla isim değişikliği uygulamaları önemli bir yer tutmaktaydı. Bu uygulamalar genel olarak Bulgaristan tarihi açısından iki dönem içerisinde değerlendirilebilir. İlk dönem 1878-1944 yılları arasını kapsar ve bu dönemdeki isim değiştirme kampanyalarının temelinde aşırı Bulgar milliyetçiliği duygusu ile Ortodoks kilisesinin temsil ettiği aşırı dini duygunun karışımı yer alır. 1944-1989 yılları arasını kapsayan ikinci dönemin temelinde ise aşırı milliyetçilik ve komünist ideolojisinin karışımı vardır(Sabev, 2012, s. 123-124).

Bulgaristan isim değiştirme uygulamalarına ilk olarak Bulgaristan Prensliği’nin kurulmasının ardından 1903 yılında ülkedeki şehir, köy, vadi ve tepe gibi coğrafi yerlerin isimlerini değiştirerek başladı ve Bulgaristan İçişleri Bakanlığı’nın 1934 yılında aldığı bir karar ile 1600 kadar yabancı kökenli yer ismi Bulgarca isimler ile değiştirildi. Yer isimlerinin değiştirilmesi 1943 yılına kadar devam ederek Dobruca bölgesindeki bütün yabancı yer adlarına Bulgarca isimler verildi (Dayığlu, 2005, s. 225). Bulgaristan'da yaşayan azınlıklara karşı yapılan ilk zorla isim değişikliği uygulamaları ise 1912-1913 yıllarında, Birinci Balkan Savaşı döneminde gerçekleştirildi. Savaş esnasında Bulgar askerinin eline geçen Rodop Dağları'nda yoğun olarak yaşayan Pomakların adları, Bulgar Patrikhanesi’nin girişimi ve yeni kurulan Bulgar idaresinin uyguladığı baskı ile değiştirildi. Bu kampanya esnasında 150.000-200.00o Pomak zorunlu isim değiştirme uygulamasına maruz kaldı. Pomakların gösterdikleri güçlü direniş sonucunda, daha çok onları Hristiyanlaştırmayı hedefleyen bu uygulamaya İkinci Balkan Savaşı’nın başlamasıyla sona erdi. Balkan savaşlarının ardından ikinci isim değiştirme uygulamaları 1937 yılında Rodop Dağları'nın merkezi olan Smolyan kasabasında Rodina adlı örgütün kurulmasıyla başlandı. Rodina örgütü temsilcilerine göre Pomaklar Müslümandı ve etnik köken olarak Bulgar'dı. Bu yüzden İslam geleneğine bağlı olan isimlerinin Bulgar adları ile değiştirilmesi gerekliydi. Bunun dışında örgüt Pomak kelimesinin yerine "Müslüman Bulgar" (Bılgaro Mohamedanin) ifadesinin kullanılmasını öneriyordu. Ancak telkin yoluyla yapılan bu kampanya fazla başarılı olamadı. Rodina teşkilatının aracılı̆̆ıyla 
Bulgaristan'da yapılmaya çalışılan isim değiştirme kampanyasının dışında, 1942 yılında Fakülte (Факултета/Fakulteta) olarak bilinen Sofya mahallelerinden birinde yaşayan Müslüman Romanların isimleri de bu dönemde değiştirildi (Sabev, 2012, s. 126).

1944 yılında Bulgaristan'da iktidara gelen komünistler ülkedeki azınlıklara haklarını geri vereceklerini taahhüt ettiler. Komünistlerin ilk yönetim yıllarında 1944-1956 yılları arasında Bulgaristan anayasası ülkedeki azınlıkları tanıdı ve onlara haklarını iade ederek korunmaları hakkında garantiler verdi. Hükümet kısa süre de olsa, azınlıkları kültürlerini yaşamaları doğrultusunda destekledi. Komünist Parti ideologları bu dönemde azınlıkların komünist ideolojiye inanarak, işçilerin sınıfsal çıkarları doğrultusunda etnik kimliklerini zamanla unutacaklarını, gönüllü olarak milli kimliklerini terk ederek sosyalist Bulgar kimliklerini kabul edeceklerini düşünmekteydi. Ancak 1950'li yıllarda Bulgar yöneticiler için endişe verici problemler ortaya çıktı. Ülkedeki Müslüman Romanlar, Tatarlar ve Pomaklar kendilerini Türk olarak niteliyordu. Bu tablo karşısında Bulgar yetkililer tek bir homojen ulus oluşturmak için radikal kararlar alınması gerektiğine karar verdiler. 1956 yılının Nisan ayında Komünist Parti Merkez Komitesinin geniş çaplı toplantısı bu konuda bir dönüm noktası oldu. Bu toplantıda azınlıkların haklarında bazı kısıtlamalara gidilmesine ve ülkedeki en büyük azınlı̆̆ oluşturan Müslümanların isimlerinin Bulgar isimleri ile değiştirilmesine karar verildi. Böylece isim değiștirmeler için kanuni bir alt yapı hazırlandı (Eminov, Turkish and other Muslim Minorities in Bulgaria, 1997, s. 5). 1956 yılındaki parti toplantısında dikkat çeken diğer bir husus ise toplantıda asimilasyon sözcügü kesinlikle kullanılmayarak onun yerine etnik birleştirme, Bulgar Romanlarının, Türklerin ve diğerlerinin sosyalist hayata entegrasyonu, sinff bilinci, parti, halkın uluslararası ve milli bilincinin yükseltilmesi, sosyalist bir yaşam tarzı ve kültürü, sosyalist ritüellerin düzenlenmesi gibi teknik ifadeler kullanılmasıydı (Eminov, Turkish and other Muslim Minorities in Bulgaria, 1997, s. 84).

1956 yılında alınan kararların ardından komünist milliyetçilerinin asimile politikalarına ilk olarak ülkenin güneybatısında, Pirin bölgesinde yaşayan Makedonlar şahit oldu. Ülkedeki Makedonların nüfusları 1956 yllında 187.789 iken 1965'te 8.750'ye düştü (Eminov, Turkish and other Muslim Minorities in Bulgaria, 1997, s. 6). Makedonlarla ilgili bu uygulamaların ardından, Aralık 1958'de Bulgar Hükümeti tarafından yayınlanan bir kararnamede Romanlar içerisinde bazı kesimlerin kendilerini Türk olarak tanımladıklarına ve çocuklarını Türk okullarına gönderdiklerine dikkat çekildi. Kararnamenin yayınlanmasının ardından Romanların Bulgarca ve Romanca olarak iki dilde yayınlanan gazeteleri yalnızca Bulgarca olarak yayınlanmaya başlandı. Tiyatroları kapatıldı. Müslüman Romanların bir bölümünün isimlerinin Bulgar isimleriyle değiştirildi. Bulgaristan yönetimi bundan sonra Türkçe eğitimine ve Müslümanların dinsel özgürlüklerine kısıtlamalar getirdi. Türkçenin Türk azınlı̆̆ın Bulgar halkı içinde asimile olmasına en büyük engellerden biri olduğunu düşünen Bulgaristan Komünist Parti (BKP) Merkez Komitesi, 1958 yllında 1958/1959 ders yllından itibaren Türk ve Bulgar okullarının birleştirilmesi ve eğitimin Bulgarca yapılması kararını aldı. Bundan sonra tüm eğitim kurumlarında Türkçe ders saatleri yavaş yavaş azaltıldı ve 1974 yılında ülkede Türkçe eğitim tamamen kaldırıldı. Müslümanlara dini baskılar başladı. Kuran kursları kapatıldı, geleneksel Türk kılık kıyafetlerini giymek, ramazanda oruç tutmak ve çocukların sünnet ettirilmesi, dini nikahın kıyılması yasaklandı. Nisan 1962'de Politbüro "Romanların, Tatarların, ve Pomakların Kendilerini Türk Olarak Tanımlamalarına Karşı Alınacak Önlemler" başlı̆̆ını taşıyan bir rapor hazırladı. Söz konusu raporda önce bu Müslüman gruplar bakımından böyle bir eğilimin nedenleri üzerinde duruldu. Sonuç olarak, Müslümanların Türk ve Arap isimlerini taşımasının, Türklerin propagandalarının etkisinde kalmalarının, 1948-1952 döneminde Rodoplar'da yaşayan Pomakların Türklerin yoğun olarak yaşadığı yerlere göç ettirilmelerinin, Türklerle yapılan evliliklerin ve askerlik hizmeti sırasında ayrı Müslüman birliklerin kurulmasının Müslüman Romanların, Pomakların ve Tatarların kendilerini Türk olarak 
Forced name change campaign applied to Turks in Bulgaria and Turkish press (december 1984-march 1985) / H. Demirhan (pp. 252-272)

tanımlamalarında en büyük etkenler olduğu belirtildi. Bu değerlendirmelerin ardından Politbüro Türklerin bu toplulukların üzerindeki etkisini ortadan kaldırmak amacıyla yerel yöneticilere söz konusu toplulukların Türk-Arap isimlerini bırakarak Bulgar isimleri almaları ve Bulgar etnik kimliğini benimsemeleri için geniş ölçekli ikna kampanyası başlatmaları direktifini verdi. Bunun dışında, yerel yönetimlerden sorumlu olan halk konseylerinde Pomakların ve Romanların Türklerin yoğun olarak yaşadığı köy ve şehirlere gitmelerine izin vermemeleri istendi. Ayrıca, Politbüro tarafından Eğitim Bakanlığı ile halk konseylerine Roman, Tatar ve Pomak öğrencilerin Türkçe eğitim yerine Bulgarca eğitim almaları, söz konusu azınlıkların diğer Müslüman öğrencilerle aynı yurtlarda barındırılmamaları ve aynı gruplar içerisinde eğitim almamaları yönünde direktifler verildi. Alınması gerekli diğer bir önlem ise Türk din adamlarının söz konusu Müslüman grupların yaşadıkları köylere atanmalarının önlenmesi oldu.

1962 yılında Politbüronun aldığı bu kararlar doğrultusunda, aynı yıl Yukarı Cuma bölgesinde yaşayan Pomakların isimlerini değiştirmek, onları dini inanç ve geleneklerinden vazgeçirmek amacıyla harekete geçildi. Parti yetkilileri ile Pomaklar arasında şiddetli çatışmalar çıktı. Bunun üzerine 1964 yılında isim değiştirme kampanyasından vazgeçildi ve Pomaklara eski isimlerinin iadesine karar verildi. Pomaklar ile ilgili geri adım atan Bulgaristan yönetimi bu kez 1965'te Müslüman Romanların isimlerini değiştirme uygulamasını başlattı. Baskılar sonucunda önceki nüfus sayımında kendilerini Türk olarak tanımlayan 100.0oo'den fazla Müslüman Roman'ın isimleri Bulgar isimleri ile değiştirildi.

Bulgaristan yönetimi 1964 yllında Pomakların isimlerini iade ettikten altı yl sonra tekrar zorla isim değişikliği uygulamaları ile ilgili kararlar aldı. 17 Temmuz 1970 tarih ve 549 sayılı kararında BKP Merkez Komitesi, Pomakların isimlerinin Bulgar isimleriyle değiştirilmesi ve giyim tarzlarına müdahale edilmesi yönünde yerel yöneticilere yeni emirler verdi. Bu kararlar uyarınca 1971-1974 döneminde bazı kaynaklara göre 120.000 bazılarına göre de 220.000 Müslüman Pomak’ın ismi zor kullanılarak değiştirildi. Bu kararlara ve isim değiştirme uygulamalarına ek olarak 18 Mayıs 1971 yllında kabul edilen yeni anayasada, Bulgar kökenli olmayan vatandaşların anadillerini öğrenme haklarının bulunduğu yönündeki düzenlemelerden başka, azınlıklarla ilgili herhangi bir düzenlemeye yer verilmedi ve azınlık kelimesi kullanılmadı (Dayığlu, 2005, s. 286-288). Yine aynı yıl yapılan Bulgaristan Komünist partinin onuncu kongresindeki programında sosyalist düşüncenin toplumun tüm katmanlarına yayılması gerektiğine ve farklı etnik köklere sahip olan milletler de sosyalist toplumun oluşması için bu farklı grupların yakınlaşması ve kaynaşması gerektiğine karar verildi. 1973'lü yıllarda medyada ilk defa birleşmiş Bulgar milletinden bahsedilmeye başlandı. 1974 Şubatındaki Bulgaristan Komünist Parti Merkez Komite toplantısında Asimilasyon politikalarına daha büyük bir enerji ile devam edilmesi kararı alındı. Birleşmiş sosyalist toplum oluşturma kampanyalarından sonra Bulgaristan'da Bulgar milliyetçisi yazarlar tamamen tek bir tip ve homojen bir toplumdan bahsetmeye başladılar. 1979 yllında Todor Jivkov Bulgaristan'daki azınlıklar sorununun toplumun kendisi tarafından ortadan kaldırıldığını ve azınlıklarla ilgili bir problemi olmadığını açıkladı (Eminov, 1990, s. 214). 1980 yılına gelindiğinde Komünist Partinin merkez komitesi sekreteri ve partinin ideoloji ve kültür politikaları sorumlusu olan Stoian Mihailov Şubat ayında komiteye partinin azınlıklara karşı uygulayacağı politikaları içeren bir rapor sundu. Raporda bilimsel ve ideolojik çalışmalar ile Türklerin Türklük bilincini sarsılarak Bulgarlık bilincinin benimsetilmesi gerektiği ifade ediliyordu. Mihailov raporunda ayrıca Bulgarlaşma sürecinin başarılı olması için Türklerin adlarının ve soyadlarının Bulgar adıyla değiştirilmesini önermekteydi. Ancak bunun riskli olduğunun ve büyük sorunlara sebep olabileceğinin de altını çiziyordu (Dimitrov, 2000, s. 8). Mihailov'un bu raporuna rağmen BKP 1984 yllında Türklerin zorla isimlerini değiştirme kampanyasını başlatacaktı. 


\title{
Zorla isim değiştirme kampanyasının sebepleri ve kararın alınması
}

Bulgar devlet adamları zorla isim değiştirme uygulamasını, Bulgaristan'daki Türk varlığını kabul etmeyen ve Türklerin kökenlerinin Bulgar olduğunu iddia eden Yeniden Doğuş (Soya Dönüş) Sürecinin bir aşaması olarak görmekteydiler. 18 Ocak 1985 tarihinde partinin genel sekreterleri ile yapılan bir toplantıda Politbüro üyesi ve BKP’nin önemli isimlerinden Georgi Atanasov'un konuşması, zorla isim değiştirme kampanyası hakkında Bulgar devlet adamlarının bakış açılarını ortaya koyması bakımından önemlidir. Atanasov konuşmasında yaşanan süreci ve bu sürecin sebebini şöyle ifade ediyordu:

\begin{abstract}
Son 10 yıl içinde Bulgar Sosyalizm Devleti’nin temellerinin sağlamlaştırılması ve etnik bütünlüğünün sağlanması adına kayda değer başarılar elde edilmiştir. Bu başarı aynı zamanda Bulgar Sosyalist devletinin önemli kazanımlarından ve Leninst çizginin takip edilmesinden kaynaklı Nisan 1956 BKP genel kurulunun çalışmasının sonucudur. 1970'lerin başında Smolyan, Pazarcık ve Blagoevgrad çevrelerinde geçmişte cebren Müslümanlaştırılmış Bulgarların (Pomakları kastediyor) torunlarının Müslüman isimleri Bulgar isimleriyle değiştirilmişti. Yeniden Doğuş Süreci’ne, bu halkın milli bilince tekrar ulaşmasına ve toplumsal Bulgar sosyalizminin yeniden inşası ve sağlamlaştırılmasına 70'li yıllarda girişilen isim değiştirme kampanyasıyla başlanmış oldu. Son yıllarda bizim çalışmalarımızla yaklaşık 250 bin Bulgaristan Romanının pasaportları değişti ve onlara Bulgar ismi verildi. Bu sayede son yıllarda görülen Türkleşme eğilimi başarısızlığa uğradı. Bununla birlikte isim değiştirme işlemlerine 70'lerdeki sürece dahil olmayan bazı Müslüman Bulgar ve karma evlilikler yapanlar arasında devam edildi. Çalışmamızı kapsayan süreçte özellikle Kırcali bölgesinde Bulgar etnik kökenli olanların sayısının beklediğimizden daha çok olduğunu tespit ettik. Birçok bölgede yaşadığı bilinen Bulgaristan Türkleri diye anılanların etnik kökeninin geçmişte Müslümanlaştırılan Bulgar neslinden olduğu belgelerle tespit edilmişti. Bunlar geçmişte farklı dönemlerde farklı etkiler altında kalarak Türkleşmişlerdir. Bu süreç 19. asrın sonunda da devam etmiş, 20. asırda bağımsız Bulgar devleti zamanında da sürdürülmüștür. Muhtemelen dinî cemaatlerin ve karma evliliklerin etkisi altında gerçekleşmiştir. İsim değiştirme süreci başlangıçta bir kaç bin kişiyle sınırlıydı, fakat daha sonra çı̆̆ gibi büyüyen bir sürece dönüştü. Çalışma şeklimize bazı birey ve ailelerin etnik kökeni hakkında incelemeler yapmakla başladık. Araştırmaya tabi tutulan bölge halkı, yaşadıkları yerleşim yerlerinin ve köylerin kökenlerinin Bulgar olduğunu teyit ettiler. Gerçekten artık Krumovgrad (Koşukavak), Momçilgrad (Mestanlı), Cebel ve diğer yerleşim yerlerinde nüfusun etnik kökeninin Bulgar asıllı olduğu belgelerle kanıtlandı. Araştırmalar sonucunda buranın halkının menşeinin Bulgar asıllı olduğunu kanıtlayan ikon, Hristiyanlığa ait objeler, toponimik öğeler, kılık kıyafet ve belge niteliğinde kalıntılar bulundu. Bütün bu kanıtlardan sonra halkın kendi geçmişleri ve kökenleri üzerinde düşünmesine ve Türk-Arap isimlerini Bulgar isimleriyle değiştirmeleri üzerine kafa yormasına ve bir sonuca varmasına mani olunamazdı..." (Istinata za "Văzroditelniya Protses”, 2003, s. 7-9).
\end{abstract}

Todor Jivkov'da aynı toplantıda yaptığı konuşmasında: "Hepimiz biliyoruz ki Bulgaristan Türkleri olarak bilinen ve kendilerini Bulgaristan'da etnik bir grup olarak görenlerin Türkiye ile hiç bir alakaları yoktur. Bu anlamda onlar Türk etnik grubuna ait olmadıkları için beş asırlık Osmanlı boyunduruğu altında yaşamış ve asimilasyona uğramış Bulgarların ahfadıdır. Bu tarihî olarak kanıtlanmıştır..." (Istinata za "Văzroditelniya Protses", 2003, s. 21) sözleriyle Bulgaristan'daki Türk varlığını inkar ederek onların etnik olarak Bulgar olduğu fikrini ispata çalışmaktaydı.

1984 yllında tamamlanmak istenen asimilasyon sürecinde Atanasov'un ve Jivkov'un Türklerin asıllarının Bulgar olduğu iddialarının yanında çekinceleri ve korkuları da bulunmaktaydı. Bu korkularının ilki Bulgaristan'da Bulgarların aleyhine gelişim gösteren nüfus artış oranlarıydı. Ülkedeki Müslüman azınlıklardaki doğurganlık oranları yüksek iken Bulgarların nüfus artış hızında ciddi azalmalar görülüyordu. İkinci olarak, artan bu nüfus oranları ile gelecekte Türklerin otonom bir Türk bölgesi kurulmasını isteyebileceklerinden korkuluyordu (Atasoy, 2011, s. 70). Ayrıca ülkedeki Türkler bazı devlet görevlilerince Türkiye'nin Bulgaristan'daki uzantısı, Türkiye’nin beşinci kolonisi ve savaş durumunda dahi Bulgaristan'a sırt çevirip Türkiye'nin yanında yer alacak güvenilmez bir kitle olarak değerlendirilmekteydi (Atasoy, 2011, s. 36). Bunların yanında, Türkiye'nin 1974 yılında Kıbrıs'a yaptığı müdahale Türkiye'nin genişlemeci siyasetinin bir hamlesi olarak görülmekte ve ileride Türkiye'nin 
Forced name change campaign applied to Turks in Bulgaria and Turkish press (december 1984-march 1985) / H. Demirhan (pp. 252-272)

Bulgaristan'daki Türkleri bahane ederek Bulgaristan'a müdahale etme girişiminde bulunacağı dile getirilmekteydi (Karpat, 20120, s. 424). Bulgaristan'da çok olumsuz bir Türk imajı vardı. Ülkenin geri kalmışlığı, sosyalist kuruculuğunda karşılaşılan güçlüklerin nedenleri beş yüz yıl Türk esareti altında bulunma gibi sebeplerde aranıyordu (Yalımov, Bulgaristan Türk Topluluğu'nun Etno-kültürel ve Dinsel Kimliği, 2016, s. 147). Bazı yazarlara göre ise isim değiştirme ve asimilasyon kampanyasının temelinde Bulgaristan'da artan sosyal, politik ve ekonomik sorunlar bulunmaktaydı. Doğu Avrupa ülkelerinin çoğunluğu gibi Bulgaristan da ekonomik durgunlukla karşı karşıya bulunmakta, halk hem siyasi hem de ekonomik reformlara ihtiyaç duymaktaydı. Diğer bir görüş de Sovyetler Birliği için Bulgaristan’ın bir deneme yeri olabileceği ve Sovyetlerin çabuk büyüyen bir etnik azınlığın asimilasyonunun mümkün olup olmayacağını öğrenmek istemesiydi (Norveç Helsinki Komitesi, 1988, s. 1467-1468).

Bulgaristan'da zorunlu isim değiştirme kampanyası ülkedeki azınlıkların asimilasyonu için radikal bir karardı. Böyle radikal bir kararın uygulanmasında 1984 yılının seçilmesi Bulgaristan adına ulusal ve uluslararası uygun koşulların oluştuğunun düşünüldüğünü göstermektedir. Bulgaristan tarafından özellikle ülkenin ana stratejik müttefiki olan SSCB'de ve ana düşmanı olan Türkiye'deki gelişmeler dikkatle izleniyordu. 1980'lerde bir yandan SSCB'nin askeri korumasını kullanırken, diğer yandan onun denetimi olmadan hareket edebilmesini sağlayan değişimler olmuştu. SSCB'nin askeri gücü 1980'lerin başında doruk noktasına ulaştı. Diğer yandan SSCB'de başa gelen liderlerin zayıflı̆̆ı uyduları üstünde sıkı bir kontrol uygulanmasını güçleştiriyordu. İsim değiştirmelerin uygulandığı sırada (Aralık 1984Ocak 1985) SSCB lideri Çernenko bir hastalığa yakalanmıştı ve hayatının son aylarını yaşıyordu. Böyle bir adımın yaratacağı uluslararası tepkiler bir Doğu-Batı çekişmesi içerisinde emilebilirdi. Bulgaristan SSCB'nin diğer uydularıyla karşılaştıııldığında neredeyse istisnasız itaatkârlık geçmişi ona başka uydulara verilmeyecek bir manevra alanı sağlyyordu. Ayrıca Türkiye'de meydana gelen 1980 Askeri Darbesi Türkiye'deki rejimin demokratik yapısına ve sağlamlı̆̆na gölge düşürmüş ve Türkiye'nin uluslararası alandaki diplomatik gücüne büyük ölçüde zarar vermişti. Bunun yanında Türkiye'nin doğusunda ortaya çıkan terör olayları ve Türkiye'nin bu olayları bastırmak için almış olduğu önlemler sık sık Avrupa ülkeleri tarafindan eleştirilmekteydi. Bu eleştirilere 1915 yılında Ermenilerin tehciri ile ilgili Türkiye'ye yapılan suçlamalar da eklenince, Bulgar yöneticilere Türkiye'nin uluslararası alanda Bulgaristan Türklerinin haklarını savunurken inandırıcı olamayacağını düşündürtüyordu (Öztürk, 2012, s. 244-245).

Bulgaristan'da zorla isim değiştirme kampanyası başlamadan önce birdenbire terör olayları görülmeye başlandı. 30 Ağustos 1984 günü Varna havaalanında bir patlama oldu ve bunun sonucunda iki kadın yaralandı. Aynı gün Filibe tren istasyonunun bekleme salonunda gerçekleşen patlamada da bir kişi hayatını kaybetti ve 42 kişi yaralandı. Bulgar hükümeti bu patlamalardan ülkedeki Türk casuslarını sorumlu tutarak Bulgar halkının gözünde Türkleri güvenilmez ve Bulgaristan'a saldıran hainler olarak takdim etti. Bun takdimin amacı Türklere uygulanacak zorla isim değiştirme kampanyasından önce Bulgar halkının desteğini kazanmaktı.

Bulgaristan Türklerine uygulanan zorla isim değiştirme kampanyasının ardından otuz beş yl geçmesine rağmen hala bu kararın kimin tarafından alındığı kesin olarak bilinmemektedir. Bu konu ile ilgili olarak 1989 yılının Kasım ayında Bulgaristan'da farklı etnik grupların yaşadığı bölgelerde parti görevlileri arasında sosyolojik bir anket yapılmış ve anket sonuçlarına göre görüşülen kişilerin \% 13.1’i bu sürecin Politbüro tarafından alınan bir karar olduğuna, \% 6.3’ü bu kararın merkez komite tarafından alındığına, \% 4,2'si ise bu kararın doğrudan Jivkov tarafından alındığına inandıkları ortaya çıkmıştır. Görüşülenlerin üçte ikisinden fazlasının (\% 69) bu kararın kimin tarafından ve nasıl alındığı hakkında hiçbir bilgisi yoktur. Görüşülenlerin \% 9o'nından fazlası ise bu kararın alınması ile ilgili olarak resmi bir 
belgenin bulunmadığına inanmaktadır (Eminov, 1997, s.86). Bulgar tarihçiler arasında da bu bilinmezlik bir tartışma konusudur. Çünkü günümüze kadar zorunlu isim değiştirme kampanyasının gerçekleştirilmesini kararlaştıran herhangi bir resmi belge bulunamamıştır. (Sabev, 2012, s. 131). Bulgaristan'da genel olarak kamuoyu bu karardan öncelikle Bulgaristan Halk Cumhuriyeti Devlet Başbakanı Todor Jivkov'u sorumlu tutmaktadır. Fakat onunla birlikte Komünist Parti'de görev yapan ve önemli konumlarda bulunan Petır Mladenov, Georgi Atanasov, Stanko Todorov, Dobri Djurov gibi kişilerin de isimleri geçmektedir. Tarihçi Stayko Trifonov bu kararın, kahve molasında, dört kişi tarafından alındığını iddia etmektedir. Ona göre bu kişiler: Todor Jivkov ile diğer parti yöneticileri Milko Balev, Dimitır Stoyanov ve Georgi Atanasov'dur. Bu konuyu ayrıca Stoyan Mihaylov ve Petır Mladenov'un da bildiğini yazmaktadır. Fakat Stoyan Mihaylov, daha sonra yazmış olduğu kitapta bu kararın kendisi için de sürpriz olduğunu vurgulamaktadır. Uzun yıllar Komünist Partisi çatısı altında, T. Jivkov'un yardımcılığını da yapmış olan Konstantin Çakırov'a göre ise bu fikri Todor Jivkov ile Kırcali bölgesinde Partinin Birinci Sekreteri Georgi Tanev ve Kircali Milletvekili Georgi Atanasov ortaya atmıştır. Çakırov, bu sebepten dolayı ilk isim değiştirmenin Kırcali ve Haskovo bölgesinde başladığını ve daha sonra Kuzey Bulgaristan'a genişletildiğini yazmaktadır (Ersoy-Hacısalihoğulları, 2012, s. 180) Sonuç olarak 1984 yllında Bulgaristan Türklerine karşı işlenen bu büyük suçun failleri tam olarak günümüzde dahi bilinememektedir.

\section{Zorla isim değiştirme uygulamaları}

Bulgaristan'da komünist idareciler 1984 yılının başlarında Bulgaristan'da sadece karışık aile olarak niteledikleri evli Türk-Bulgar çiftler ve Pomaklarla akrabalık bağı olan kişilerin isimlerini değiştirmekle işe başladılar (Sabev, 2012, s. 130). 1984 yllının Aralık ayına kadar bu şekilde karışı ailelere mensup yaklaşık 50.00o kişinin isimleri değiştirildi (Dimitrov, 2000, s. 8). 1984 yılının Aralık ayı geldiğinde Bulgaristan Devlet Güvenlik Komitesi (KDS) önceden belirlediği Türklerin önderleri durumunda olan ve isim değiştirme kampanyasında direnebileceğini düşündüğü milliyetçi Türk gençlerini düzmece bir seferberlik kampanyası ile gözaltında almaya başladı. Askere alınanlar arasında 50 yaş üzerinde seferberlikten muaf olanlar, hasta ve raporlu olanlar da vardı (Gülmen, Bulgaristan Türkleri Tarihinden Esintiler, 2011, s. 126). Kırsal bölgelerde yaşayan ve avcllı yapan Türklerin ellerinden av tüfekleri toplandı. (Öztürk, 2012, s. 246) Sorunun büyüklüğü göz önüne alınarak, zorla isim değiştirme kampanyasının güvenilir bölgesel parti liderleri, polis memurları, ve çok sayıda asker kullanılarak çok dikkatli ve koordinasyonlu bir şekilde gerçekleştirilmesi planlandı. Zorla isim değiştirme uygulamalarının iki aşama şeklinde gerçekleştirilecekti. Aralık 1984-14 Ocak 1985 tarihleri arasında ilk aşama olarak Güneydoğu Bulgaristan'da Türklerin yaşadığı Rodoplar bölgesinde isimler değiştirildi. Bu kampanya çok gizli tutulmuş, sadece bölgedeki parti komitesinin birinci sekreterleri, parti ve devlet yetkilileri resmi olarak bilgilendirilmişti. Güneydeki Türklerin isimleri değiştirilirken Kuzeydoğudaki Türklere sadece kendilerinin asıl Türk olduğu, Rodop bölgesindeki Türklerin aslen İslamiyeti seçen Bulgarlar olduğu söylendi (Eminov, 1997, s. 86). Bu söylemle Bulgaristan Türkleri arasında bir ayrım yapılarak toplu bir direniş hareketinin önüne geçilmek isteniyordu. Güneydeki Türklerin isimlerinin değiştirilmesi tamamlandığında, kuzeyde yaşayan ve Rodoplar bölgesinden evli olan bazı Türkler arasında Bulgarlar ile evli kalmak istemediklerini söyleyerek eşlerinden boşanmak veya onları terk etmek isteyenler görüldü (Eminov, 1997, s. 86).

Bulgaristan'daki isim değiştirme kampanyası 10 Aralık 1984 tarihinde Bulgaristan İçişleri Bakanı Dimitri Stoyanov'un İstihbarat görevlisi General Petar Stoyanov'a yazdığı resmi yazı ile başladı. Yazıda BKP il örgütlerine ve iç işlerine bağlı polis birliklerine ülkedeki tüm Türklere Bulgar ad ve soyadları verilmesi emredilmekteydi. Stoyanov’un gönderdiği yazıya göre isim değiştirme kampanyası Aralık 1984 
Forced name change campaign applied to Turks in Bulgaria and Turkish press (december 1984-march 1985) / H. Demirhan (pp. 252-272)

tarihinde başlayıp, Şubat 1985'te bitirilecekti. İki, üç ay gibi kısa bir sürede uluslararası kuruluşların ve medyanın dikkatini çekmeden, yaklaşık 850.000 Türk'ün adının sinsice değiştirilmesi öngörülmekteydi. Zorunlu isim değiştirme kampanyasının yapılması için özellikle kış ayları seçilmişti. Bunun sebebi Aralık-Ocak aylarında, bol kar yağışıyla çok sert geçen kış mevsimi yerleşim birimleri ile bölgeler arasındaki ulaşım ve haberleşmeyi zorlaştırarak bir yörede olup bitenleri, diğer yörede yaşayan Türklerin öğrenme olanaklarını ortadan kaldırmaktı. Bulgar idareciler bugünkü iletişim olanaklarının olmaması ve kış koşulları ile yaşananların gizli kalacağını düşünmekteydi (Atasoy, 2011, s. 106-107).

Bulgaristan'daki zorunlu isim değiştirme uygulamaları şehirlerde ve kırsal bölgelerde farklılıklar gösteriyordu. Kırsal bölgelerde uygulamalar şöyleydi: Köylerin etrafı milis (polis) ve gerektiği takdirde ordu birlikleri tarafindan sarllıyordu. Yer yer tanklar ve köpekler de bu kuşatmaya katılıyordu. Köye giriş ve çlkışlar yasaklanıyor, Bulgar memurlar ev ev dolaşarak gönüllü isim değiştirme dilekçelerini dağıtıyor ve kişilerden bir Bulgar ismi seçmelerini istiyorlardı. Seçenlere hemen yeni kimlikleri veriliyordu. Tüm köy isim değiştirdikten sonra kuşatma kaldırılıyordu (Lütem, 200o, s. 169). Bazen de köylüler köy meydanlarına veya muhtarlıklara davet ediliyorlardı. Burada isimlerini gönüllü aldıklarını belirten bir dilekçe imzalatılıyor ve önceden hazırlanmış bir listeden isim seçmeleri istenerek isim değişikliği işlemi tamamlanıyordu. Bulgar yetkililer bazen zorla ismini değiştirmek istedikleri Türklere bir değil üç dilekçe imzalatmaktaydı. Bu dilekçelerin tarihleri birbirinden farklıydı. Örneğin biri on yıl öncesinin, diğeri beş ve üçüncüsü günümüz tarihlerini taşıyordu (Çapın, 1985, s. 10) Bu dilekçeleri imzalayan Türkler üç kez farklı tarihlerde Bulgar makamlara isimlerinin değişmesi için başvuruda bulunmuş gibi gösterilmekteydi. Bulgaristan'da Türk azınlığa karşı yapılan ilk isim değişikliği uygulaması güney Bulgaristan'da Kırcali yakınındaki Gorski İzvor köyünde 24 Aralık 1984 günü gerçekleştirildi. Aynı gün akşam saat 20.oo'de Binbaşı Ovçarov, sözde Bulgarlaştııllan ilk Türk köyünde isim değişikliğinin kansız bir şekilde başarı ile bittiğini bağlı olduğu komutanına müjdeledi ve önceden hazırlanmış program doğrultusunda Bulgar müziği eşliğinde köy meydanında Bulgar halayı (Meşhur Pravohoro) oynayarak bunu kutladı (Atasoy, 2011, s. 110). Bu dönemde Bulgaristan'da yaşları 70-75 arasında değişen ve Bulgarlardan oluşan ihtiyar heyetleri kurulmuştu. Bu heyetler Türk köylerini ziyaret ediyorlardı. Heyet köye geldiğinde Türk olan bir aile için meclis kurup "Biz bu köyün en eskileriyiz. Sizin ana ve babalarınız Bulgardır. Ancak Osmanlı zamanında sizler zorla Türk yapıldınız, şimdi ise aslınıza dönüyorsunuz" diyerek bu ailedeki bireyleri isimlerini değiştirmek için ikna etmeye çabalıyordu. Bu heyetlerde Türk yoktu. Heyetin görüşünü dinleyen Bulgar makamları bundan sonra aileye mensup olan Türklerin gönüllü veya gönülsüz, ölü veya diri isimlerini değiştirmekteydi (Milliyet, İnönü Bulgaristan'da Durum Vahim, 1985, s. 12)

Kasabalarda ve şehirlerde ise zorla isim değişikliği uygulamaları iş yerlerinde gerçekleştiriliyor direnen Türklere işlerini kaybedecekleri söyleniyordu. ${ }^{3}$ Bazı Türklerin isimleri ise yedek asker alındıkları askeri kamplarda değiştirildi. Bu dönemde askere alınan Türklerin aileleri ile görüşmelerine izin verilmiyordu. Etrafları Bulgar askerler tarafından çevrildiğinde ordudaki görevli subay ya da savunma bakanlığında görevli bir memur kendisine ordudaki bütün Türklerin Bulgar ismini almasının zorunlu olduğunu

28 Ocak 1985 günü Hürriyette yayınlanan bir haberde Bulgaristan'ın Asenovgrad Kentindeki “Asenova Krepost”fabrikasında Bulgar ismi almayan Türklerin işe sokulmadıklarının haberi veriliyordu. Habere göre Fabrikanın genel müdür Mühendis Z. Basamakov'un imzasıyla 16 Ocak 1985 tarihinde 21 numaralı genelgede Türklere uygulanacak insanlık dışı yöntemler şöyle sıralanmaktaydı: Müslüman Bulgarların tekrar kazanılması konusunda alınacak tedbirlerin etkinlikleri arasında aşağıda belirtilen hususlara uyulmasını emrediyorum:1- 1 Ocak'tan itibaren 1985 yll içinde 76 numaralı form gereğince işbaşı, yeniden konulan Bulgar isimleri ile yapılacak.2-İdari hizmetler, doktor viziteleri, ilaç verme, seyahat kartları tanzim edilirken de, aynı hususlar uygulanacaktır.3- Toplum yerleri ile işyerlerinde, Türk dilinin kullanılmasına son verilecektir.4-Adını değiștirdiğine ilişkin gerekli belgeleri ibraz etmeyen tüm Türk ve Arap isimli şahıslar, işyerine bırakılmayacaktır. İşbu emir, tüm kuruma bilgi ve uygulama için iletilecektir. Emrin uygulanması ve kontrolü, ünite yöneticilerince yürütülecektir.(Kemal, Bağlum, Bu İnsanlı̆ga sığmaz, Hürriyet, 28 Ocak 1985) 
söylüyordu. Eğer Türk asker bunu reddederse üstlerine itaatsizlik etme suçu ile askeri mahkemede yargılanmakla tehdit ediliyordu. Daha da ileri gidilerek askere ailesinin yalnız olduğu ve onlarında aynı uygulamalar ile karşı karşıya kaldıkları hatırlatılıyor, onların kendisinin yardımına ihtiyaç duyabileceği, karşı gelirse ailesine de zarar vereceği ifade ediliyordu. Her şeye rağmen isim değiştirmeyi kabul etmezse koğuşa kilitleniyor ve kendisine birkaç saat verilerek Bulgar adlarının bulunduğu listeden bir isim seçmesi isteniyordu. Birçok kişi bu şartlar karşısında listeden isim seçmek zorunda kalmaktaydı. Eğer hala Bulgar kimliği almamak için direnirse, eskort eşliğinde çalışma kamplarına gönderiliyor ve gönüllü olarak Bulgar ismini aldığı belgeyi imzalayana kadar hapsediliyordu. Askerde zorla isim değiştirme uygulamaları devam ederken yerel parti görevlileri de polis nezaretinde askere alınan kişilerin ailelerini ziyaret ederek oğullarının/eşlerinin/babalarının askeri bir düzenlemeden dolayı isimlerini Bulgar isimleri ile değiştirdiğini bildiriyorlardı. Aile üyelerinin de isimlerinin değişmesi gerektiğini izah ediyorlardı. Eğer aile bireyleri buna rağmen isim değiştirmeyi reddederlerse onlara da askerde olan yakınlarına yapıldığı gibi tehditler savruluyordu. Özellikle birçok kadın isimlerini değiştirmeyi reddederek askerde bulunan erkekleri eve gelene kadar beklemek istemişlerdi (Eminov, 1997, s. 88-89).

İsimlerini değiştirmek zorunda bırakılan Bulgaristan Türkleri Bulgar isimlerini alırken bazı hususları göz önünde tutmak istiyorlardı. Bunlardan ilki isimlerini tercüme ederek yeni isimler almaktı. Örneğin: Nuri -Svetlin, Nuriye-Svetlina oldu. Bazılarının isimlerinin Türkçe ilk harfi hangisi ise buna göre Bulgarca ismi de o harfle başlıyordu. Örneğin Sevim, Selime, Saime, Seniha-Sevda oldu, Ahmet, AliAsen; Orhan, Osman-Orlin; Naim-Naum ve Hikmet-Hristofor oldu. Bazı kişiler ise Bulgar hükümetine tepki olarak o dönemin politikacılarının isimlerini aldılar. Örneğin Todor Jivkov, Lyudmila Jivkova, Petır Mladenov gibi isimler alınmıştı. Fakat uygulamada en çok Türkçeye yakın isimler tercih edilmişti: Sabri -Sevdalin; Mehmet Ali-Madjar; Ali -Alipi; Deniz-Denisse (Ersoy-Hacısalihoğulları, 2012, s. 190) .

İsmini değiştirmek istemeyen Türkler, kampanyanın ilk günlerinde Bulgar yetkililer köye geldiklerinde soğuğa aldırmadan dağlara ya da ormanlara kaçarak oralarda sabahlayarak isimlerinin değiştirilmesini önlemek istemişlerdi. Ancak bu kaçışlar kesinlikle bir çözüm değildi. Tercüman Gazetesi 26 Ocak 1985 tarihinde yaşananları özetleyen bir mektuba sayfalarında yer vererek ülkedeki durumu o günlerde şöyle anlatıyordu:

\begin{abstract}
"Çatır çatır yandık. Bulgar makamları bize baskı ve zulümlerini arttırdılar. İsimlerimizi, nüfuslarımızı değiştiriyorlar. Bunu yaparken de zor kullanıyorlar. Dediklerini yapmayanları tüfek dipçikleriyle dövüyorlar. Tabancaları, tüfekleri şakaklarımıza, beyinlerimize dayayıp zorla dilekçeler, evraklar imzalatıyorlar. Okur-yazarlar, üniversite okuyanlar ve diğer gençler bu evrakları imzalamak istemiyorlar. Bunları döverek kollarını arkaya bağlıyorlar ve parmaklarına kırmızı boya döküp, bu belgelere parmak bastırıyorlar. Sonrada döve döve hapse götürüyorlar, işkencelere tabi tutuyorlar. Kurtar bizi Türkiye... Seni de aldattılar, bizi de aldattılar. Biz onlara ne yaptık ki bizi vahşice eziyorlar. Her gece evlerimiz baskına uğruyor. Karda kışta dağlarda yatıyoruz. Aç-susuz günler geceler geçiriyoruz. Çocuklarımız ölüm derecesinde hasta. Yakalayabildiklerini telef ediyorlar. Şimdiden yüzde altmışımız bitti. Yılbaşından on gün önce soykırıma başladılar. Hasköy sancağını silip süpürdüler. Bizim de yarımız gitti. Ölürüz de Bulgar olmayı. Yani seneye kadar bitirecekleri bizi. Türkiye! Bütün dünya kurtarın bizi! Yetişin imdadımıza! Bizleri ayaklandılar, isyan ettiler diye kurşuna diziyorlar. Polis asker hepsini üzerimize saldılar. Yetişin... Kurtarın bizi...” (Tercüman, Bulgaristan'dan Gelen Mutfak Önlüğünden Çıkan Gizli Mektup, 1985, s. 6).
\end{abstract}

1985 Ocak ayından sonra Bulgaristan’da isim değiştirmeden yaşamak çok zordu. Bankadan para çekmek veya maaş almak için yeni Bulgar kimliği ile başvurmak zorunluydu. Hastanede tedavi görmek için de yeni kimliğinize ihtiyaç vardı. Caddede herhangi bir ulaşım aracında kimliklere bakıldığında Türk ismini taşıyan kimlik varsa geçersizdir damgası vurulmakta, kimliğin sahibi para cezasına çarptırılmakta, hatta isim değiştirme kampanyasına muhalefetten hapse atılmaktaydı (Eminov, 1997, s. 89). Yeni doğan 
Forced name change campaign applied to Turks in Bulgaria and Turkish press (december 1984-march 1985) / H. Demirhan (pp. 252-272)

bebeklere Bulgar ismi verilmediği takdirde doğum belgesi verilmiyor, Bulgaristan kimlikleri ile başvurmayanların evlenme başvuruları kabul edilmiyordu (Ataöv, 1989, s. 145).

Bulgaristan Türkleri kendilerine uygulanan zorla isim değiştirme kampanyasına karşı bazı bölgelerde direnişler oldu. Bu direnişler genellikle toplu olarak değil bireysel olarak yapılan direnişlerdi. Ancak 1718-19 Ocak 1985 günlerinde Kotel ilçesine bağlı Alvanlar köyünde Alvanlılar ve onlara desteğe gelen çevre köylerin halkı, iki gün boyunca ellerinde hiç bir silah olmaksızın zırhlı araçların önlerine canlı bedenlerini koyarak köylerinde zorla isim değişikliği uygulamalarının yapılmasını önlemek istemişlerdi. 4 Bu direniş Bulgaristan'da isim değişikliğine karşı yapılan tek toplu direniş örneğiydi. Alvanlar direnişinin dışında Kırcali bölgesinde de ismini değiştirmek istemeyen Türkler barışçıl şiddet içermeyen protesto yürüyüşleri yaptılar. 23-25 Aralık 1984 tarihinde Kırcali yöresindeki Benkovski köyünde, 24 Aralık’ta Tosçalı'da, 26 Aralık’ta Kirkova'da ve Mestanlı'da bu yürüyüşler gerçekleşti. Ancak Bulgar ordu ve polis birlikleri göstericilere karşı çok sert davrandı. Çıkan olaylarda ölenler ve yaralananlar oldu (Atasoy, 2011, s. 112-113). Gösterileri düzenleyenler Bulgaristan'daki toplama kamplarına ve cezaevlerine gönderildiler. Buralarda ağır hakaretlere ve işkencelere maruz kaldılar. Bu dönemde hayatını kaybeden Türklerin sayısı hakkında tam bir veri mevcut değildir. Bulgar kaynakları bu dönemde hayatını kaybedenlerin sayısını 7 gösterirken, Bulgaristan'daki Hak ve Özgürlükler Partisi yetkilileri bu sayıyı 24 olarak belirtmektedir (Atasoy, 2011, s. 113) Türk basını ise bu dönemde yapmış olduğu haberlerde ölenlerin sayısını farklı vermekteydi. Tercüman gazetesi 7 Şubat 1985 tarihinde Razgrad ve Şumen sancağında katledilen Türklerin sayısını 850 olarak ifade ederken (Tercüman, 1985, s. 1) Bilal Şimşir yazmış olduğu eserinde bu sayıyı 800 ile 2500 arasında ifade etmekteydi. (Şimşir, 2012, s. 363) Bu dönemi değerlendiren diğer çalışmalarda da farklı sayıların verilmesinden dolayı bu dönemde hayatını kaybeden Türklerin sayısını kesin olarak tespit etme imkanı yoktur.

İsim değiştirme kampanyasında sonra Bulgaristan'da üzerinde Türkçe yazı bulunan mektuplar kişilerin tespit edilemediği gerekçesiyle iade edildi. Bu dönemde Türklerin yaşadığı köylere baskınlar oldu. Ev ev dolaşan ordu ve polis güçleri ile milisler Türklere ait olan giysileri, geleneksel kıyafetleri, annelerden kızlara geçen ağaçtan yapılmış çeyiz sandıklarını dışarıya çıkardılar. Kur’an tercümelerini hatta ateizm veya komünist propaganda yapan Türkçe kitaplar dahil bütün Türkçe yayınları topladılar. Evlerinde Türkçe yayın bulunduranlar cezalandırıldı. (Eminov, 1997, s. 89). Bulgar Hükümeti, Türk bölgelerinde yapılan mezalimi ve katliamı duyurdukları için başta İngilizce BBC olmak üzere Hür Avrupa (Radio Free Europe), Hürriyet (Radio Liberty) ve Alman radyolarının yayınlarını aksatmaya başladı. Türk bölgelerinde yabancı radyoların dinlenmesi yasaklandı ve kısa dalga istasyonların dinlenebildiği güçlü alıcıların satışları sınırlandırıldı (Tercüman, 1985, s. 1)

\section{Bulgaristan hükümetinin zorla isim değiștirme uygulamaları sürecindeki politikaları}

Bulgaristan Komünist Parti lideri Todor Jivkov 18 Ocak 1985 tarihinde yapılan parti toplantısında Bulgaristan Hükümeti’nin Türkler hakkındaki düşüncesini şöyle dile getiriyordu: “ Bulgaristan Türkleri diye adı geçenler Türk milletinin bir parçası değil ve kesinlikle Türk milletiyle ortak özellikleri de bulunmamaktadır. Bulgaristan Türkleri şeklinde adlandırılanlar Bulgar milletinin bir parçasıdır ve iki millet tarihi bağlarla birbirlerine bağlıdır. Şu anda da bizim toplumsal düzenimize bağlı ve tabidirler. Gelecekte de böyle olacaktır. Dolayısıyla Türkiye'nin Bulgaristan'ın içişlerine karışması için hiç bir hakkı ve hiç bir dayanağı yoktur. Böyle bir girişim doğal olarak ihlal sayılacak ve uluslararası hukuka aykırı

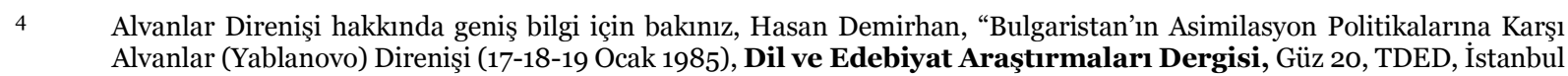
2019 
olacaktır" (Istinata za "Văzroditelniya Protses", 2003, s. 21) Yine Jivkov 30 Mart 1985 tarihinde gerçekleştirilen Bulgar Komünist Partisi Merkez Komitesi Sekretaryasının toplantısında Bulgaristan Türklerinin isimlerinin değiştirilmesi ile bu azınlıklarla ilgili geçmişten kalan problemlerin çözülmesi için önemli bir adım atıldığını, 15-20 sene içinde bu problemlerin çözülüp tamamen unutulacağını ve bundan sonra İslam diniyle bağlarının tamamen kesilmesi için tedbirler alınması gerektiğini söyleyerek (Sabev, 2012, s. 133) Bulgaristan hükümetinin Türklere uygulamış olduğu bu insanlık dışı uygulamayı, sanki yıllardır yapılan bir yanlış anlamanın düzeltilmesiymiş gibi ifade ediyordu.

1985 yılının Ocak ayından itibaren Türk ve dünya basını Bulgaristan'daki Türklerin isimlerinin değiştirilmesini sayfalarına haber yaparken, Bulgaristan basını ve devlet adamları sessiz kaldılar. Bulgaristan'ın Türkiye büyükelçisi Argir Konstantinov'a Ocak ayının ilk günlerinde Bulgaristan'da Türklere karşı yapılan isim değişikliği zorlamaları sorulduğunda elçi bunun kesinlikle doğru olmadığını, Türklerin isim alma haklarının Bulgaristan anayasası tarafından korunduğunu, Türklerin isimlerinin ancak istekleri doğrultusunda kanuni bir işleyiş sonunda değiştirileceğini söylüyordu. (Eminov, 1990, s. 204). Ancak aynı yılın Şubat ayında Büyükelçi Konstantinov ifadesini değiştirerek, Bulgaristan'daki Türklerin isimlerinin değiştirildiğini açıkça itiraf etti. Konstantinov 19 Şubat 1985 günü Dışişleri Bakanı Vahit Halefoğlu ile yaptığı görüşmede isim değişikliği kampanyası ile ilgili açılamalarda bulundu: 1Türklerin adlarının ve kimliklerinin değiştirildiği olayı doğrudur. Ancak bu, kişilerin kendi istekleri doğrultusunda yapılmaktadır. 2-Baskı haberleri yalandır, Türkiye ile Bulgaristan'ın arasını bozmak isteyen kaynaklar tarafından kasten yayılmaktadır. 3-Bulgar hükümeti, iki ülke arasında anlayış, dostluk ve iyi komşuluk ilişkilerinin sürdürülmesini samimi olarak arzu etmekle birlikte, Bulgar vatandaşı olan Türklerle ilgili hareket ve tutumların Bulgaristan'ın iç işlerine ait olduğu kanısındadır (Milliyet, 1985, s. 1). Bulgaristan'ın resmi haber ajansı Sofya Press de Türk ve dünya basınında Bulgaristan'da yaşananlar hakkındaki haberler üzerine bir bildiri yayınladı. Zorla isim değiştirme kampanyasında Türklere karşı yapılan her türlü zulmü yalanlayan ve gerçekleri örtmeye çalışan bildiri şöyleydi:

\begin{abstract}
Son yıllarda Bulgaristan özel bir hedefti. Batının iyi bilinen kindar güçleri, Bulgaristan’ı her soydan ve boydan günah işleyen bir ülke olarak göstererek inatla lekeleme ve kara çalma çabası içindedir. Örneğin Papa'ya karşı girişilen suikast Bulgar izi, uyuşturucu maddelerle yasadışı ticaret, batıyı istikrarsızlaştırma, vb. hep bu çabaların ürünleridir. İftira sahipleri, attıkları iftiraları kanıtlamak durumunda olmadıklarından, Bulgar Türkleri (Bulgaristan Türkleri) denilenlerin adlarını zorla değiştirmek ile ilgili daha da dizginsiz bir anti-Bulgar kampanyasına başvuruyorlar. Bulgar yurttaşlarının adlarının zorla değiştirilmesi konusunda yazılan her türlü yazılar düzmecedir ve asılsızdır. Bulgar demokrasi kanunları, ülkenin her yurttaşına kendi adını seçme ve dilediğinde adını değiştirme hakkı veriyor. Ülkemizdeki Müslümanlar da bu hakka sahiptir. Kaldı ki Müslümanlar, halkın ve devletin bölünmez, eşit ve tam haklı bir parçasıdır. Bulgaristan Halk Cumhuriyeti yurttaşları bu yasal haklarından ne iç ne de dış etki ya da telkinle asla yoksun edilemezler. Bulgar Türkleri (Bulgaristan Türkleri) denilenlerin Türk ulusu ve devletiyle hiçbir ilgisi yoktur. Onlar Bulgar yurttaşıdır ve ülkenin yasaları gereğince Bulgar yurttaşlarının tüm haklarına ve ödevlerine sahiptir. Bulgar yurttaşlarının gönüllü olarak adlarını değiştirme süreci, gerek kişisel yaşamları açısından, gerekse Bulgaristan Halk Cumhuriyeti anayasasının 53. Maddesince güvence altına alınan vicdan ve din özgürlüğü açısından olumsuz hukuksal sorunlara yol açmıyor. (Güneş, 1985, s. 7).
\end{abstract}

Yukarıdaki örneklerde de görüldüğü gibi Bulgaristan, isim değiştirme kampanyasında Türklere uygulanan baskıları her firsatta inkar etti. İsim değiştirmelerin gönüllü olduğu ve Bulgaristan'da yaşayan Türklerin asıllarının Bulgar olduğu yalanlarını ortaya attı. Bu dönemde Bulgaristan'da aydın denilen bazı Türklere de baskılar yapılarak zorla isim değiştirme uygulamalarının gönüllülük esasına göre yapıldığını anlatan bildiriler okutuldu ve bunlar haber yapılarak tüm dünyaya duyurulmaya çalışıldı (Lütem, 2000, s. 205). 
Forced name change campaign applied to Turks in Bulgaria and Turkish press (december 1984-march 1985) / H. Demirhan (pp. 252-272)

Bulgaristan basını bu dönemde ülkesinde Türklere karşı yapılan zorla isim değiştirme kampanyasına karşı tamamen ilgisiz kaldı (Eminov, 1990, s. 204). Yaşananları gizli tutmak için ise 1985 yılı boyunca Bulgaristan'da Türklerin yaşadığı bölgelere yabancı diplomatların ve gazetecilerin girmesini yasakladı. Ülkede yabancı basına tam bir sansür uygulanmaktaydı. The News Day (23 Ocak 1985), The New York Times ( 8 Şubat 1985), The Christian Science Monitor (3 Nisan 1985) ve The Economist (14 Aralık 1985) sayfalarında Bulgaristan'daki Türk bölgelerine gitmek isteyen diplomatların ve gazetecilerin başvurularının sürekli olarak reddedildiği haberlerini verdiler. Yine bu dönemde Bulgaristan'daki Türklerin Sofya'da bulunan elçiliklerine başvuruları engellenmekteydi. Fransız haber ajansı çalışanları, Bulgaristan hükümetinin Türklere karşı tutumlarını eleştiren bir haber yaptığından dolayı ülkeye yedi ay boyunca giriş izni alamadılar (Ataöv, 1989, s. 150).

Bulgaristan komünist parti idarecileri aldıkları kararlarla dışarıya haber sızmasını engellemeye çalışırken Türklerin yaşadığı bölgelere sık sık ziyaretlerde bulunarak Türkleri yatıştırmaya ve yaşananları onlara kabullendirmeye çalışıyorlardı. Bu ziyaretlerde mesaj her bölgede aynıydı. Bulgaristan'da Türk yoktur. Pomaklar ve Türkler, Osmanlı zamanında İslamı kabul ederek Türkleşen Bulgarlardır. Bulgarca konuşan Pomaklar ve Türkler gerçek kimliklerine yirminci yüzylın ikinci yarısında gönüllü ve aniden isimlerini değiştirerek kavuşmuşlardır. Bu dava kapanmıştır (Eminov, 1997, s.5). Bundan sonra isim değişiklikleri bu halkın Türk köleliğinden kurtuluşu adına bir bayrama dönüştürülmelidir (Istinata za "Văzroditelniya Protses", 2003, s. 26).

\section{Zorla isim değiştirme uygulamalarına Türk hükümetinin ve kamuoyunun tepkisi}

Bulgaristan Hükümeti 1984 yılının Aralık ayında Türklere karşı başlattığı zorla isim değiştirme kampanyasını gerek kış şartları ve gerekse iletişim araçlarına uygulamış olduğu sıkı sansür sonucunda gizleyebileceğini ve ortaya çıkan gerçekleri de inkar ederek bu süreci başarıyla tamamlayabileceğini düşünmekteydi. Ancak Bulgaristan'da yaşananlar Ocak ayının ikinci haftasından sonra Türk ve dünya basınında yer almaya başladı. Türk ve dünya kamuoyları Bulgaristan'da Türklere karşı yapılan zulümden haberdar oldu. Tük Hükümetinin bu yaşananlara karşı ilk günlerdeki tutumu gayet temkinli ve soğukkanlı idi. Türkiye gerekli girişimleri yapmadan önce Bulgaristan'da yaşananlar hakkında kesin ve net bilgiler almak ve yaşanan problemleri iki ülke arasında gerçekleşecek görüşmelerle, kavga zeminine götürmeden akılcı bir şekilde çözmek istiyordu. Dönemin Dışişleri Bakanı Vahit Halefoğlu 27 Ocak 1985 tarihinde Milliyet Gazetesi’ne verdiği beyanatlarla hükümetin bu durum karşısındaki tavrını şu sözleriyle açıklıyordu: "Konuyu en yüksek düzeyde ele aldık, dikkatle izliyoruz. Gerekli teşebbüsleri yapıyoruz. Bize intikal eden haberlerden duyduğumuz endişeleri dile getiriyoruz. Bu yaşananların iki ülke arasındaki ilişkilere müspet tesir yapmayacağını söylüyoruz. Ancak bunları yaparken, Bulgaristan ile yakın ilişkilerimizi ve komşuluğumuzu göz önünde tutarak, eğer problemler varsa her iki tarafın da ilişkileri zarar görmeden halledilmesini arzuluyoruz" (Milliyet, Endişeliyiz, 1985, s. 6) Gazetenin Bulgaristan'dan gelen vatandaşlarımızın tepkileri hakkındaki sorusuna ise verdiği cevap şöyleydi: "Onların duygularını elbette anlıyoruz. Oradaki yakınları ile ilgili bazı haberler alıyorlar ve bu haberler gayet tabii olarak önce onları rahatsız ediyor. Bunu saygıyla karşılıyoruz. Onlara anlayışla cevap vermek lüzumunu da hissediyoruz. Fakat onların da istedikleri amaca varılması için daha soğukkanlı ve daha gerçekçi bir politika güdülmesinin daha doğru olacağına inanıyoruz. Bu politikanın sonuçta onları daha memnun bırakacağına itimat ediyoruz. Halledilecek meseleler varsa, bunların iki taraf arasında soğukkanlı yaklaşımla ve diyologla daha kolay halledileceği görüşünde olduğumuz için bu yolun biraz sabırla takip edilmesini doğru buluyoruz" (Milliyet, Endişeliyiz, 1985, s. 6). Bu dönemde hükümette başbakanlık görevinde bulunan Turgut Özal'da bir yurt gezisi sırasında Bulgaristan Türklerinin durumu ile ilgili sorulan bir soruya verdiği cevabında, Türklerin Bulgaristan'da yaşadıkları ile ilgili bu ülkedeki 
resmi Türk memurlarınca yaşananların bizzat tespit edilmediği, Yunanistan ile yaşanan sorunlara bir tanesinin daha eklenmek istenebileceği ve Bulgaristan'ın zaten terör ve Ağca olaylarından dolayı dünyada bozulan imajını daha da bozmak istemeyeceğini düşündüğünü söyledi. Sorunun çözümü ile ilgili olarak ise Türkiye'nin sorunu diyolagla ve ilişkileri bozmadan çözmeye çalıştığını, cumhurbaşkanının da bu görüşte olduğunu ve dikkatli olunması gerektiğini belirterek hükümetin bu konudaki görüşlerini özetledi (Tercüman, Özal:Bulgaristan Olaylarına Batının İlgisi Manidar, 1985, s. 1). Cumhurbaşkanı Kenan Evren'de Bulgar Devlet Başkanı Todor Jivkov’a bir mesaj göndererek sorunun iki ülke arasındaki iyi komşuluk ve dostluk ilişkileri çerçevesinde anlayışla ele alınmasını umduğunu bildirmiş, Jivkov mesaja cevap olarak konuyla bizzat ilgileneceğini ve aralarındaki dostluğun sorunu çözmeye yeteceğini belirterek cevaplamıştı (Cumhuriyet, Evren, Jivkov'dan Çözüm İstedi, 1985, s. 8).

Bulgaristan Türklerine karşı yapılan zorla isim değişikliği kampanyası ve baskılar karşısında Türkiye'deki muhalefet partileri konuya karşı son derece ilgiliydiler. Zaman zaman da hükümetin temkinli ve soğukkanlı tavrını eleştirdiler ve hükümetin yaşananlar konusunda daha ciddi adımlar atması gerektiğini dile getirdiler. Bu eleştirilerden basına yansıyan ilk haber Milli Demokrasi Partisi (MDP) Hatay Milletvekili Murat Sökmenoğlu'nun TBMM Başkanlığına bir soru önergesi vererek Dışişleri Bakanı Vahit Halefoğlu'ndan konuyla ilgili bilgi istemesi oldu. Sökmenoğlu, Dışişleri Bakanı Halefoğlu'ndan şu sorulara açıklık getirmesini istemişti: 1- Bulgaristan'da Kurcali'ye bağlı Mestanlı ilçesinde işkence ile isim değiştirme bahanesiyle kaç soydaşımız katledilmiştir? 2- Türkiye için işkence iddialarında bulunan basının, bu olayla dikkati çekildi mi? 3- Batı Trakya'da bütün Türklere reva görülen bu olaylara seyirci kalanlar için Türkiye'nin girişimleri ne olmaktadır? (Cumhuriyet, 1985, s. 1) Aynı partiden Bitlis Milletvekili Faik Tarımcıŏ̆lu da 22 Ocak 1985 tarihinde TBMM Başkanlığı'na bir gensoru önergesi vererek Başbakan Turgut Özal'dan Türk ve dünya basınında çıkan haberlerin doğru olup olmadı̆̆ı ve eğer doğru ise hükümetin bu konuda tedbir alıp almadığı konusunda bilgi almak istedi (Tercüman, Bulgarlar Türklerin Federatif Cumhuriyet Kurmasından Korkuyor, 1985, s. 6). Şubat ayında muhalefet partilerin yetkilileri Bulgaristan'da yaşananları soykırım olarak nitelediler ve hükümete olan eleştirilerini daha da sertleştirdiler. Muhalefet parti temsilcilerinin 10 Şubat 1985 tarihli Tercüman Gazetesi'ne yansıyan eleştirileri şu şekildeydi; Halkçı Parti (HP) Genel Başkanı Necdet Calp:

Bulgaristan'da soydaşlarımıza karşı girişilen baskı ve zulüm olayları hakkında önce Türk basınında yer alan haberler, arkasından da inanılır yabancı haber kaynaklarında yer alan tüyler ürpertici olaylara rağmen, hükümetin suskunluğu devam etmektedir. Bu konuda sorular üzerine Sayın Başbakan'ın vaki kısa beyanları Türk kamuoyunu aydınlatıcı nitelikte olmadığı gibi milli vicdanı da tatmin etmemiştir. Bulgaristan'da ne olup bittiğini, Türk kamuoyu ve siyasi partiler bütün açılklı̆ı, ile öğrenmelidir. Bulgaristan'daki soydaşlarımızın feryadı karşısında Türk Parlamentosunun suskun kalması mümkün değildir.

\section{Milliyetçi Demokrasi Partisi Genel Başkanı Turgut Sunalp:}

ANAP iktidarı devrinde maalesef Türk dış politika uygulamasının pek istikrarlı ve şahsiyetli bir görüntü verdiği iddia olunamaz. Bu genel görüntü içinde Bulgaristan'ın asırlardır kendileriyle birlikte yaşayan ırkdaşlarımıza uyguladığı baskıyı son günlerde arttırarak, emlaklarına el koyma, isimlerini Bulgarlaştırma ve direnenleri öldürmeye kadar varan bir noktaya getirmesi dikkat çekici, tahammül edilemez bir durum yaratmıştır. Böylece Türklere karşı girişilen hasmane hareketler ve cinayetler soykırım olmaktan da ileri gitmiştir. Bu saldırıların demir perde gerisinde cereyan etmesi, dünya kamuoyuna yansımasına set çekmektedir. Hükümetin kararlı bir tutum içine girmesini, gereken her türlü tedbirin alınmasını istemekteyiz. Konu, ırkdaşlarımızın malına ve canına dönük günlük politika aleti haline getirilmemesi gereken milli bir konudur.

Doğru Yol Partisi (DYP) Genel Başkanı Yıldırım Avcı'da konuyla ilgili düşüncelerini şöyle dile getirdi: 
Forced name change campaign applied to Turks in Bulgaria and Turkish press (december 1984-march 1985) / H. Demirhan (pp. 252-272)

Soydaşlarımızın ıstırabını ve çektiklerini üzüntü ile karşılıyoruz. Bulgaristan'daki Türklere insanlık, kanun ve komşuluk münasebetleri dahilinde insan haklarına yaraşır bir şekilde muamele edilmesini isteriz. Gazetelerde aktüel halde uzun zamandan beri sürdürülen haberlerden anlaşıldığına göre, Türklere karşı yapılan zulüm insanlık ölçülerini aşmıştır. DYP olarak, bu hareketler karşısında devletçe alınacak her türlü tedbirin yanındayız. Ancak hükümetin bu soykırım karşısında suskunluğunun manasını anlamıyoruz. Bu hayati meselede, hükümetin her Türkün yüreğini sızlatan bu hadise hakkında mecliste Türk kamuoyunu aydınlatması icap eder. Toplantının gizli yapılacağı ifade edildiğine göre, meclis dışındaki partilerin temsilcilerinin de müzakereleri takip etmesinin gayet tabii olacağı kanaatindeyiz.

\section{Muhafazakâr Parti (MP) Genel Başkanı Ali Koç’ta tepkisini şu sözlerle ifade etti:}

Her devlet kendi soyundan olan insanları hangi ülkede bulunurlarsa bulunsunlar koruma cihetine gitmiştir. Soydaşlarına yapılan baskı ve zulmü milletlerarası teşkilatlara, Adalet Divanı'na, Kızılay, Kızıl Haç gibi kuruluşlara götürerek üzerlerine düşeni yapmaya çalışmaktadır. Türk devleti ve hükümeti, bugünlerde insanlık dışı bir soykırımla karşı karşıya bulunan Bulgaristan'da yaşayan soydaşlarımızın ve diğer ülkelerdeki Türk unsurların maddi ve manevi haklarını korumak, kollamak için her türlü tedbiri almaya mecburdur. Bu konuda hükümetin suskunluğunu ve olayı kamuoyundan saklama çabasını esefle karşılıyoruz.

Refah Partisi Genel Başkan Yardımcısı Rıza Ulucak’nn da eleştirileri şu şekildedir:

Hariciyemiz ne yazık ki, âmme efkârını ve partileri gelişmelerden haberdar etmemektedir. Yunanistan'da da Türklere zulüm yapılmaktadır. Zulüm son zamanlarda o kadar ayyuka çıkmıştır ki, yabancı gazetelerde bile yer almıştır. Bilhassa, Bulgaristan'ın Türklere reva gördüğü zülum bir soykırımdır, bir insanlık suçudur. Bu durum karşısında devlet olarak en sert tedbirleri almak durumundayız. Her iki devlet de müsamahadan, hoşgörüden anlayacak millet değildir. En şen’i fiilleri işlemekte tereddüt etmezler. Şimdi de Bulgar anayasasında yer alan bir hükmü işletmemek için Bulgaristan'daki Türk azınlığını yok etme girişimindedirler. Bugüne kadar derin bir sessizliğe bürünen ANAP hükümetinin gereken tedbirleri süratle alacağına ve TBMM'nin bu konuda hükümete yön vereceğine inanıyoruz.” (Tercüman, Bulgaristan'a Karşı Tedbir Alınmalıdır, 1985, s. 10).

Muhalefetin bu sert eleştirilerine karşı Dışişleri Bakanı Vahit Halefoğlu Bulgaristan'daki olayların en yüksek seviyede ele alındığını ve endişelerin Bulgar makamlarına iletildiğini belirten açıklamalar yaptı. Devlet Bakanı Mesut Yılmaz'da Bakanlar Kurulu toplantısında Bulgaristan'da meydana gelen olayların ele alındığını açıkladı ve Sofya büyükelçisi Ömer Engin Lütem olaylarla ilgili kendisinden bilgi alınmak üzere Türkiye'ye çağrıldığını belirtti. Başbakan Turgut Özal 14 Şubat günü dönemin Cumhurbaşkanı Kenan Evren ile yaptığı haftalık görüşmelerinden sonra göç olabileceği sinyalini vererek, Bulgaristan'daki Türklere kapıların açılabileceğini ifade etti (Tercüman, Özal: Gerekirse Kapıları açarız, 1985, s. 1).

Türkiye Büyük Millet Meclisi 20 Şubat’ta yapılan gizli bir oturumda Bulgaristan Türklerinin durumunu görüşı̈ ve 22 Şubat’ta Bulgaristan'a diplomatik bir nota verdi.5 Türkiye bu notasında Türklere karşı yapılan baskıların sonlandırılmasını, bakanlar düzeyinde görüşmeler yapılarak Türkiye’ye göç etmek isteyen Bulgaristan Türklerinin göçü için yeni bir göç antlaşmasının konuşulmasını, Bulgaristan'da Türklerin yaşadığı bölgelere Türk parlamentosundaki üyelerden oluşan veya Türk ve yabancı diplomatların oluşturacakları bir heyetin ziyaretine imkan verilerek, basında çıkan haberlerin doğru olup olmadığını gözlemlenmesine izin verilmesini istemekteydi (Eminov, 1990, s. 204). Türkiye ayrıca notasında Bulgaristan'ın iç işlerine müdahale anlamına gelecek hiçbir davranışın Ankara'dan kaynaklanmayacağını, dikkatle belirtti (Barlas, 1985, s. 7). Ancak Bulgaristan Türkiye’nin ülkesindeki Türklerle ilgilenmesini "içişlerine müdahale" olarak yorumladığını ve göç antlaşmasını reddettiğini açıkladı. Bunun üzerine Türkiye Bulgaristan'daki Türklerin sorunlarını çözmek için Birleşmiş Milletler

Türkiye bu tarihten sonra Bulgaristan'a 4 Mart 1985'te ikinci notasını, 1o Nisan 1985'te üçüncü notasını ve 7 Ağustos 1985 'te de dördüncü notasını vermişti. Bu notalar hakkında geniş bilgi için bakınız Ömer e. Lütem age, s. 302-338) 
Genel Kurulu, İslam Konferansı Örgütü, Avrupa Güvenlik ve İşbirliği Konferansı ve Avrupa konseyi gibi uluslararası platformlara taşımak zorunda kaldı (Konukman, 1990, s. 56). Ayrıca bu dönemde TBMM Başkanı Necmettin Karaduman'ın teşvikiyle Bulgaristan'daki Türklere yapılan baskıların yerinde incelenmesi için Bulgaristan'a bir parlamento heyetinin gönderilmesi çalışmalarına başlandı. Bu amaçla Parlamentolararası Birlik Türk Grubu Başkanı Barlas Doğu, Parlamentolararası Birlik Bulgar Grubu Başkanı Dr. Peter Voudov'a bir mektup göndererek Bulgaristan’ı ziyaret etmek istediğini bildirdi (Milliyet, Karaduman: Baskıların Sürdüğü Endişesi Dağılmadı, 1985, s. 7).

Bulgaristan'daki Türklerin yaşadığı mezalim karşısında Türk kamuoyunu en çok harekete geçiren kurumlar ise, daha önceki yıllarda Bulgaristan'dan Türkiye'ye göç eden Türklerin kurmuş oldukları dernekler oldu. Bu dernekler Bulgaristan'da zorla isim değiştirme kampanyasının başlamasıyla birlikte harekete geçerek siyasi parti yetkililerini ve devlet kurumlarını Bulgaristan'da yaşananlarla ilgili olarak bilgilendirdiler ve bu zulmün durdurulması için onlardan yardım talebinde bulundular. İstanbul'da yaşayan Bulgaristan göçmenleri bir heyet oluşturarak Ocak ayı içerisinde topladıkları binlerce imza ile birlikte Ankara'ya geldi ve hazırladıkları dosyaları devlet, hükümet ve siyasi parti yetkililerine sundular. Göçmen heyetinin hazırlamış olduğu dosyada Bulgaristan hükümetinden talep edilenler şunlardı:

\begin{abstract}
1-Parti Merkez Komitesi Politbürosu'nun Türk soykırımına ilişkin 1969, 1970 ve 1984 yıllarında onayladığı ve bundan sonra uygulamaya geçirdiği gizli Bulgarlaştırma kararlarının hükümsüz bırakılması. 2-Silah gücüyle isimleri değiştirilen 500.000 soydaşımızın ad ve soyadlarının geri verilmesi. 3-Tutuklu evlerinde ve temerküz kamplarına sürülen, polis dairelerinin mahzen katlarında darp edilen, aç ve susuz bırakılan, verilere göre toplam 12.500 erkek ve kadın soydaşımıza uygulanan baskılara son verilmesi ve söz konusu soydaşlarımızın serbest bırakılması. 4- Ordu ve polis birliklerinin denetiminde bulunan Rodopların, Trakya'nın, Deliorman'ın, Dobruca'nın Gerlova'nın ve Tozluk'un silahlı militaristlerden arındırılması. 5-BM İnsan Hakları Beyannamesi'nin, Helsinki Nihai Belgesi ve Bulgaristan Anayasası'nın hak ve özgürlükleri ile ilgili maddelerinin Bulgaristan'da da uygulanması. Böylece iki milyon soydaşımızın yaşamlarının garantiye alınması. 6- Türk düğün ve bayramlarını, örf ve adetlerini, ölüm ve doğum törenlerini siyasi suç kapsamına alan yasağın kaldırılması. 7-Soydaşlarımızla her türlü iletişimin polis denetiminden arındırılması ve uygar yasalar doğrultusunda yapılması. 8-Turist olarak Bulgaristan'ım ziyaret edeceklerin akrabalarını oturdukları şehir ve köylerde güvenli bir şekilde ziyaret etmelerinin sağlanması. 9-Kapatılan Türk okullarının yeniden açılarak Türk çocuklarının Türkçe eğitim-öğretim görmeleri. 10-Türklerin eşit vatandaş olarak en ağır sektörlerde çalışmalarına son verilmesi. 11-Soydaşlarımıza yönelik işkence, zulüm, insanlığa aykırı, onur kırıcı cezalar ya da işlemlerin kaldırılması. 12- Soydaşlarımızın düşünce, vicdan, din ve dil özgürlüklerinden yoksun bırakılmaması, kanunların herkese eşit olarak uygulanması (Cumhuriyet, Bulgaristan'a 12 İstek, 1985, s. 8).
\end{abstract}

Göçmen dernekleri daha sonra Şubat ayı içerisinde bu isteklerini birkaç küçük değişiklikle Birleşmiş Milletlere telgraf yoluyla bildirerek uluslararası alana taşıdılar (Tercüman, Bulgar Zulmü Gizli Oturumda Görüşüldü, 1985, s. 7). Yine dernek mensupları 26 Ocak 1985 tarihinde 11 kişilik bir heyetle Anıtkabir'i ziyaret ettiler ve İstanbul'da yaşayan 15 bin Bulgaristan Türk göçmeninin imzaladığı dilekçeyi çeşitli belgelerle ve bazı fotoğraflarla birlikte Cumhurbaşkanı'na, Konsey Üyelerine, Genelkurmay Başkanlığı'na ve diğer ilgililere ulaştırdılar. Tüm dünyayı Bulgaristan'da yaşanan soykırımı durdurmak için Bulgaristan'a siyasal ve ekonomik ambargo uygulamaya davet ettiler (Milliyet, Evren ve Üruğ'a 15 bin İmzalı Dilekçe, 1985, s. 6). Göçmen dernekleri üyelerinin Bulgaristan'daki akrabalarından kendilerine gönderilen ve Bulgaristan'daki Türklerin acı durumlarını anlatan mektupları basın ile paylaşmaları, Türk kamuoyunu harekete geçirerek hükümeti bu konuda daha cesur adımlar atmaya mecbur biraktı.

Türk kamuoyunda birçok kurum Bulgaristan'da yaşananları kınayan duyurular ile Bulgaristan Türklerine desteklerini gösterdiler. Ankara Üniversitesi Rektörü Prof. Dr. Tarık Somer’in imzası ile 
Forced name change campaign applied to Turks in Bulgaria and Turkish press (december 1984-march 1985) / H. Demirhan (pp. 252-272)

Ankara Üniversitesi Senatosu da bu kurumlardan birisiydi. Ankara Üniversitesi’nin duyuru metni şu şekildedir:

\begin{abstract}
Bulgaristan'daki Türkler, uluslararası hukuk kuralları ve iki ülke arasındaki mevcut anlaşmalar uyarınca azınlık statüsündedir. Buna rağmen Bulgaristan 1946'dan sonra bu anlaşmaları uygulamamak hususunda ısrar etmektedir. Bulgaristan'ın Türk azınlığa karşı sistemli bir şekilde hareket ettiği, Türkleri en ağır işlerde çalıştırdığı, idari kadrolarda ve orduda Türk soyundan gelenlere görev vermediği yakından bilinmektedir. Bu ayrım ve kasıtlı hareketleri yıllardan beri müşahede eden Türkiye, Bulgaristan'daki Türk azınlığın bugün karşılaştığı baskı, şiddet ve katliam haberlerinden büyük endişe duymaktadır. Emek sarf edilerek bugünkü düzeye getirilmiş olan iyi ilişkilerin gerilemeye başlamasından iki ülkenin de kazanacağı hiçbir şey bulunmadığı açıktır (Cumhuriyet, AÜ: Bulgaristan, Türklere Azınlık Statüsü Anlaşmasını Uygulamıyor, 1985, s. 6).
\end{abstract}

27 Şubat tarihinde de üniversitelerarası kurul toplantısında Bulgaristan'daki Türklere uygulanan baskıları kınayan bir bildiri yayınlandı. Bildiride Bulgaristan'da Türklere uygulanan baskının ilkel topluluklarda dahi rastlanmayacak kadar insanlık dışı olduğu ve katliamın gerçekliğinin kamuoyunca artık kabul edildiği kaydedildi. Bulgar hükümetinin azınlıkların korunmasına ilişkin Türk-Bulgar Dostluk Antlaşması, Bulgaristan Anayasası ve Paris Barış Antlaşması’nda öngörülen hükümlere uymadığı vurgulandı ve şöyle denildi:

Türk milleti, kendisiyle beş asır birlikte yaşayan Bulgar azınlığa, sınırsız din ve vicdan hürriyeti tanıdığı halde, yirmi birinci asra yaklaştığımız bu dönemde Bulgar Hükümeti, bugün kendi ülkesinde yaşayan Türk azınlığa en tabii insan haklarını bile tanımamakta ve bu suretle bütün dünya devletlerinin ortak kabul ve inancına tevdi edilen, İnsan Hakları Evrensel Beyannamesi ile kabul edilmiş bulunan ilkeler de açıç̧a ihlal edilmektedir.

Türk Bulgar ilişkileri konusunda iyi komşuluk münasebetlerinin yaratılması ve sürdürülmesinde fayda gören Türkiye'de mevcut 28 üniversitenin rektör ve temsilcilerinden oluşan Üniversitelerarası Kurul, Türk milletini haklı ve derin bir infiale sevk eden bu insanlık dışı tutum ve davranışlara son verilmesi yolunda, Bulgar Hükümetini yukarıda belirtilen taahhütlerine sadakat göstermeye davet eder" (Cumhuriyet, Özal: Değil 500 Bin, Çok Daha Fazla Soydaşımıza Kucak Açarız , 1985, s. 5)

\title{
Zorla isim değiştirme sürecinde Türk basını
}

Bulgaristan'daki Türklere uygulanan zorla isim değiştirme kampanyası (1984 Aralık-1985 Ocak) ve bu kampanyanın Türk kamuoyuna ve basınına nasıl yansıdığı konusunda yapılan bu çalışmada 1984 yılının Aralık ayından itibaren 1985 yılının ilk iki ayını kapsayan bir zaman zarfında Türk basınında konu ile ilgili çıkan haberler incelendi. Bu dönem değerlendirildiğinde, gerçekten de Türk basınının Bulgaristan'da Türklere karşı uygulanan zorla isim değiştirme uygulamalarının, zulmün ve asimile politikalarının Türk ve dünya kamuoyuna duyurulmasında çok büyük bir etkisinin olduğu gözlemlendi. Türk basını bu dönemde tüm gazeteleri ile ortak bir tavır sergilemiş ve Bulgaristan Türklerinin yaşadıkları dramı ulusal ve uluslararası platformlara taşımayı bilmişti. Genel hatlarıyla Türk basınında çıkan haberler sınıflandırıldığında ilk olarak gazete sayfalarında akademisyenlere ve emekli büyükelçilere yer verilerek onların yazılarıyla Bulgaristan Türklerinin tarihi serüveninin dile getirildiği görülmektedir. Bulgaristan Türklerinin sorunlarına tarihi bir perspektiften bakmaya çalışan bu yazılar, Türklerin 1984-1985 yılları arasında karşı karşıya kaldıkları isim değiştirme sürecinin tarihsel sebeplerini anlatmaya yoğunlaşmaktadır. ${ }^{6}$ Emekli büyükelçilerin yazılarında ise genellikle Türk Hükümeti'nin artık harekete geçmesi gerektiği ve yapılacak hamlelerin ne olacağı konusunda tavsiyeleri bulunmaktadir.

\footnotetext{
6 Bulgaristan Türklerinin tarihi ile ilgili olarak Hasan Şenyurt’un yazdı̆̆ (Bulgaristan Türklerinin Dramı”, Milliyet, 21-23 Şubat 1985, s. 11), Bulgaristan'daki Türklerin Kökeni, Milliyet, 19 Şubat 1985, s. 2 vb. haberler örnek gösterilebilir.
Adres | Adress


Bu dönemde Türk basınında hükümeti sert bir şekilde eleştiren ve onun politikalarını pasif gören yazılara yer verilmesi dikkat çekmiştir. Hükümete karşı yapılan eleştirilere bazen de muhalefet parti mensuplarının beyanatları dahil edilmiştir.7 Ayrıca incelediğimiz dönemde Bulgaristan Türklerinin yaşadığı mezalimi dile getiren ve bu konuda Türk devletini harekete geçirmeye çalışan Bulgaristan Türklerinin Türkiye'de kurdukları derneklerin faaliyetleri ve bu derneklerin hükümete başvuruları ve talepleri hakkında geniş bilgilerin verildiği yazılar çok sayıda mevcuttur. Bulgaristan dernekleri bu dönemde adeta Ankara’yı abluka altına almışlar, sık sık hükümet temsilcileri ve muhalefet liderleri ile bir araya gelerek Bulgaristan'da yaşayan akrabalarının sorunlarını ve bu sorunların çözülmesi için önerilerini dile getirmişlerdir. Türk basını Bulgaristan Türklerinin kurmuş oldukları bu derneklerin, TRT gibi Türkiye'deki bazı kurumların bu konu üzerinde yeterince durmadığı gibi bazı eleştirilerini de sayfalarına taşımıştır. ${ }^{8}$

İsim değiştirme kampanyası sürecinde basında dikkat çeken diğer bir unsur ise gazetelerin gizli bir şekilde Türkiye'ye ulaşan Bulgaristan'daki Türklerin isim değiştirme uygulamaları sırasında yaşadıkları zulmü anlatan mektuplardır. Bu mektuplar incelendiğinde gerçekten duygusal ve insanların acılarını ortaya koyan hikayeler ile dolu oldukları görülmektedir.9 Tercüman Gazetesi'nin 20 Ocak 1985 günü Soydaşlarımız Bulgar Zulmünü Gözyaşları İçinde Anlatıyor adlı başlık altında yer vermiş olduğu bir mektup buna örnek gösterilebilir. Mektupta soydaşımız yaşadıklarını şu şekilde ifade etmektedir:

\begin{abstract}
"Karağaç Pınarı altında da buldu canavar bizi. Oradan toplayıp getirdiler, yine değiştirdiler adlarımızı. Biz bilsek bile gerçek olmayacağını belki gün gelir de olur. Biz de Türk toprağına ayak basarız diye gönül eyleyip o ümitle yaşardık. Şimdi artık o ümidimizi de kaybettik, o da kaybolup gitti. Bizlerin artık yaşamamıza neden kalmadı. Böyle yaşamaktansa ölmek daha iyi bizim için. Ey benim kardeşim! Beni çok üzen derdin biri de şu ki, doya doya kardeşimin adını anayım, dilimden düşürmeyeyim diye abimin adını oğluma vermiştim. Fakat şimdi o ad defterlerden kayboldu. Yerine ... adını koydular. Çocuk bahçesi de yakın orada muallimler ... diye haykırdı mı, onu öldüreceğim geliyor. Yine sabretmeye çalışıyorum. Fakat bu böyle çekilmez. Aklımızı aldıracağız düşünürken hepimiz. Denizler kağıt olsa, ağaçlar kalem, yazsam günlerce yazsam yine bitmez dertlerimiz. Sizin kısmetiniz varmış gitmişsiniz. Yerimize yaşayın. Fakat bizi unutmayın. Ayda yılda da olsa ne olur oradan bir mektup yazın.” (Tercüman, Soydaşlarımız Bulgar Zulmünü Gözyaşları İçinde Anlatıyor, 1985, s. 6)
\end{abstract}

Türk basınının bu dönemde Bulgaristan'daki zorunlu isim değiştirme uygulamaları ile ilgili olarak yaptığı diğer bir haber türü ise, Türkiye’ye daha önce gelmiş veya bir şekilde yakın zamanda Türkiye'ye sığınmış olan Bulgaristan Türkleri veya onların yakınları ile yapılmış olan röportajlardı. Bu röportajlarda Türkler yaşadıklarını ve akrabalarından aldıkları acı dolu haberleri gazete okuyucuları ile paylaşmaktaydı.10 Bu görüşmelere Bursa Namık Kemal Mahallesi Şanlı Sokağı’nda oturan ve yakın

Evren Jivkov’a Mesaj Gönderdi, Tercüman, 16 Ocak 1985, s.3, Bulgarlar Türklerin Federatif Cumhuriyet Kurmasından Korkuyor, Tercüman, 23 Ocak 1985, s. 6, İnönü: Bulgaristan'a Gerekirse Müeyyide Uygulanmalı, Tercüman, 29 Ocak 1985, s. 3, Bulgaristan İçin Gizli Görüşme Kabul Edildi, Cumhuriyet, 14 Şubat 1985, s. 1, Bulgaristan’a Karşı Tedbir Alınmalıdır, Tercüman, 10 Şubat 1985, $\quad$ S. 10 vb. haberler örnek gösterilebilir.

8 Bulgaristan'da Izdırap Var, Tercüman, 13 Subat 1985, s. 1, Evren ve Üruğ'a 15 Bin İmzalı Dilekce, Milliyet, 27 Ocak 1985, s. 6, Jivkov’a Mesaj Gönderdiler, Milliyet, 3 Şubat 1986, s. 3, Yüzlerce Türk İntihar Etti, Tercüman, 10 Şubat 1985, s.10, Bulgar Zulmü Gizli Oturumda Görüşüldü, Tercüman, 21 Şubat 1985, s.7, Bulgaristan Endișesi, Cumhuriyet, 21 Ocak 1985, s. 1, Bulgar Zulmü”, Milli Gazete, 8 Ocak 1985,s.1,Bulgaristan Göçmenleri TRT’yi Protesto Etti, Güneş, 22 Ocak 1985 haberleri örnek gösterilebilir.

9 Recep'i Tabanca Zoruyla Hıristiyan Yaptılar, Milliyet 24 Ocak 1985, s.6, Sigara Paketleri İcerisinde Mektuplasıyorlar, Milliyet, 23 Ocak 1985,s.10, Soydaşlarımız Bulgar Zülmunu Gözyaşları İçerisinde Anlatıyor, Tercüman, 20 Ocak 1985, s. 6, Türkler haklarını İsteyince Kiyamet Koptu, Milliyet, 23 Ocak 1985, s.10 Adlarının Değiştirilmesinden sonra, Bulgaristan'dan Gelen Mektup: "Kardeşiz Ama, Artık yabancı Olduk", Milliyet, 29 Ocak 1985, s. 12 vb. haberler örnek gösterilebilir.

10 Beni Çırılçılak soydular, Milliyet, 29 Ocak 1985, s.3, Hastaneler, Ölü Yaralı Dolu, Kırktan Fazla Ölü Var, Güneș, 1 Șubat 1985, s.6, Evden toplayıp götürüyorlar, Çok fena İşler Oluyor, Milliyet, 15 Şubat 1985, s.7, Tuna Üzerindeki İşkence Adası, Milliyet, 26 Şubat 1985, s.3 vb. haberler örnek gösterilebilir. 
Forced name change campaign applied to Turks in Bulgaria and Turkish press (december 1984-march 1985) / H. Demirhan (pp. 252-272)

zamanda akrabalarını ziyaret için Bulgaristan'a giden Necip ve Fatma isimli yaşlı çift ile yapılan görüşme örnek olarak verilebilir. Röportajda Fatma Hanım Bulgaristan'da gördüklerini şöyle anlatmaktadır:

Bulgaristan'daki Türklere yapılan zulüm dağlara taşlara sığmaz. Hastaneler ölü ve yaralı Türklerle dolu. Benimle birlikte hapse atılan bir Türk, Kırcali bölgesinde kırktan fazla ölü olduğunu söyledi. Türklerin isimlerini, nüfus cüzdanlarını zorla değiştiriyorlar. Her şeyi asker zoruyla yapıyorlar. Bulgar halkı karışmıyor. Uzak vilayetlerden askerler getiriyor, onların baskısıyla istediklerini yaptırmaya çalışıyorlar. Boyun eğenleri, ismini değiştirmeyi kabul edenleri gerekli evraklarını imzalattıktan sonra serbest bırakıyorlar. Bunlar Bulgarlığl kabul etmiş oluyor. Ama isminin, nüfus cüzdanının değiştirilmesini istemeyenlerin vay haline. Olmadık işkence yapıyor ve öldürüyorlar” (Güneş, Hastaneler, Ölü-Yaralı Dolu, Kırktan Fazla Ölü Var, 1985, s. 6)

Türk basını bu dönemde Bulgaristan Türklerinin sorunlarını anlatırken dünya basınında bu konuyla ilgili olarak çıkan haberleri de sütunlarına taşıyarak, Bulgaristan Türklerinin sorunlarına diğer yabancı ülkelerin bakış açıları hakkında da değerlendirmelerde bulunmuştur. ${ }^{11}$ Sonuç olarak, Türk basını isim değiştirme kampanyası sırasında ve ondan sonraki bir buçuk aylık süre içerisinde Bulgaristan Türklerine yapılan bu asimilasyon kampanyasına Türk kamuoyunun ilgisini çekmeyi başarmış ve bu ilgiyi canlı tutarak dönemin hükümetini harekete geçmesi için zorlamıştır.

\section{Sonuç}

Bulgaristan komünist idaresi 1944 yllında Bulgaristan'a hakîm olduğunda, ülkedeki azınlık mensuplarına kendilerinden önceki faşist yönetimlerin ellerinden aldıkları haklarını geri vereceklerini ilan etti. Bu vaat Bulgaristan'daki Türk azınlık için bir umut olmuş ve Türkler 1946 yllında ülkede yapılan seçimlerde komünist partinin de üyesi olduğu Vatan Cephesi koalisyonuna oy vermişlerdi. Komünist yönetimin ilk yıllarında ülkedeki azınlıkların kendi kültürlerini sürdürmesi desteklendi. Bu dönemde Türkler kendi dillerinde gazete ve dergi çıkardılar, tiyatro ekipleri kurdular, gelenek ve göreneklerini yaşatmak için festivaller düzenlediler. Ancak birkaç yll sonra Bulgaristan Komünist Parti yöneticileri Türk azınlığı desteklemekten vazgeçerek, kendilerinden önceki iktidarların yaptıkları gibi Türkleri asimile etme çabasına giriştiler. 1946 yılında Türk okulları devletleştirildi. 1958-1959 eğitim-öğretim yılında ise bu okulları Bulgarlaştırıldı ve Bulgaristan'da Türkçe eğitimine yasaklar getirildi. 1970’li yıllarda ülkede Türkçe eğitim veren kurumlar ortadan kaldırıldı.

1950'li ve 1960’lı yıllarda komünist idareciler Türk azınlı̆̆ın kültür seviyesinin yükselmesiyle birlikte etnik kimliklerinden zamanla uzaklaşacağını ve gönüllü olarak sosyalist Bulgar kimliklerini kabul edeceklerini düşünmekteydiler. Ancak bu yıllarda yapılan araştırmalarda Türklerin kimliklerini muhafaza ettikleri ve ülkedeki diğer Müslüman azınlıkların da kendilerini Türk olarak tanımladıkları ortaya çıktı. Bunun üzerine komünist idareciler 1956 yllındaki parti toplantısında ülkedeki Müslümanların isimlerinin Bulgar isimleri ile değiştirilmesi konusunda kararlar aldı. Bulgaristan'da ilk olarak nüfus oranları Türklere göre daha düşük olan Müslüman Romanlar ve Pomaklar üzerinde isim değiştirme uygulamaları yapıldı. Bu yıllarda Türklerin dini ve örfi ritüelleri yasaklandı. 1970'li yıllardan itibaren Bulgaristan'da Türklerin kökenlerinin Bulgar olduğu ile ilgili asılsız tezler ortaya atılmaya başlandı. 1980'li yıllarda tüm bu propagandalara rağmen Türkler arasında Bulgar kimliğini kabul edenlerin sayısı çok azdı. Bunun yanında ülkedeki nüfus artış oranları incelendiğinde Müslümanların oranlarının Bulgarlardan en az dört kat daha yüksek olduğu ortaya çıkmıştı. Aynı yıllarda Türkiye, 11 Dünya Basınında Bulgar Mezalimi”, Tercüman, 23 Şubat 1985, s. 4, Bulgar Zulmü Dünya Basınında, Milliyet, 24 Şubat
1985, s. 7 vb. haberler örnek gösterilebilir. 
doğuda PKK terörüyle uğraşmak zorunda kalmış ve ülkede yaşanan 1980 Askeri Darbesi, batılı devletlerin gözünde Türkiye’nin prestij kaybına uğramasına neden olmuştu.

Bulgaristan Komünist Parti yöneticileri 1984 yılında ulusal ve uluslararası ortamın uygun olduğuna kanaat getirerek ülkelerindeki Türklerin isimlerini bir aylık kısa bir süre içinde değiştirerek homojen bir Bulgar ulus hayalini gerçekleştirmeye karar verdiler. Aynı yllın Bulgar silahlı güçleri ve komünist parti yetkilileri Aralık ayının sonunda Türklerin yaşadıkları bölgelerde zorla isim değiştirme kampanyasını başlattılar. Zorla isim değiştirme kampanyası yaklaşık bir ay içerisinde tamamlandı ve 850.00o Türk'ün ismi değiştirildi. Bundan sonra Bulgaristan'daki Türklerin varlı̆̆ tamamen inkar edildi. İsmini değiştirmemek için direnenler cezaevlerine ve toplama kamplarına gönderildiler ve buralarda işkencelere maruz kaldılar.

Türk kamuoyu Bulgaristan'daki Türklere dayatılan bu isim değiştirme kampanyasından ancak 1985 Ocak ayının ilk haftasında haberdar olabildi. Türk Hükümeti’nin bu dönemdeki ilk tepkisi temkinli davranmak ve yaşanan bu sorunları Bulgaristan ile karşılıklı görüşmeler yaparak çözmek şeklinde oldu. Ancak Bulgaristan'ın uzlaşmaz tavrı karşısında Türkiye'de tavrını sertleştirdi ve Bulgaristan Türklerinin haklarını uluslararası platformlarda savunmak için girişimlerde bulundu. 1985 yılının Ocak ve Şubat aylarında Türk basını Bulgaristan'da yaşananlara kayıtsız kalmadı ve bu konuyla ilgili olarak yüzlerce haberi sütunlarına taşıdı. Özellikle Bulgaristan'da yaşananların anlatıldığı ve kaçak yollardan ülkemize ulaştırılan mektupların yayınlanması, Türk kamuoyunda büyük bir infiale sebep oldu. Mektuplar ve göçmenler ile yapılan röportajlar, Bulgaristan Türklerinin yaşadıkları zorlukları ve kendilerine uygulanan zulmü gözler önüne seriyordu. Daha önce ülkemize gelip yerleşen Bulgaristan göçmenlerinin kurdukları derneklerin faaliyetleri ve basınımızın onlara olan desteği sayesinde, Türk kamuoyu Bulgaristan'da yaşayan soydaşlarına uygulanan mezalimin farkına vardı. Bu zulmün ortadan kalkması için Türk Devleti iktidarı ve muhalefeti birlikte hareket ederek mücadeleyi başlattı.

\section{Kaynakça}

Ataöv, T. (1989). The Turks of Bulgaria. Ankara Üniversitesi Siyasal Bilgiler Fakültesi Dergisi , 135152.

Atasoy, E. (2011). Bizden Olan Ötekiler Asimilasyon Kıskactnda Bulgaristan türkleri. Bursa: MKM Yayıncilık.

AÜ: Bulgaristan, Türklere Azınlık Statüsü Anlaşmasını Uygulamıyor. (1985, Şubat 9). Cumhuriyet .

Barlas, M. (1985, Şubat 23). Dikkatli Bir Nota. Milliyet .

Bulgar Zulmü Gizli Oturumda Görüşüldü. (1985, Şubat 21). Tercüman.

Bulgaristan'a 12 İstek. (1985, Ocak 25).Cumhuriyet .

Bulgaristan'a Karşı Tedbir Alınmalıdır. (1985, Şubat 10).Tercüman.

Bulgaristan'dan Gelen Mutfak Önlüğünden Çıkan Gizli Mektup. (1985, Ocak 26). Tercüman.

Bulgarlar Türklerin Federatif Cumhuriyet Kurmasından Korkuyor. (1985, Ocak 23).Tercüman.

Çapın, H. (1985, Ocak 23). Türkler Haklarını İsteyince Kıyamet Koptu. Milliyet .

Dayığlu, A. (2005). Toplama Kampından Meclis'e Bulgaristan'da Türk ve Müslüman Azınlğı. İstanbul: İletişim.

Demirhan, H. (2019) .Bulgaristan'ın Asimilasyon Politikalarına Karşı Alvanlar (Yablanovo) Direnişi (1718-19 Ocak 1985), Dil ve Edebiyat Araştırmaları Dergisi, 20, 415-446

Demirhan, H. (2019). Sözlü Anlatımlarla 1984-1989 Yılları Arasında Bulgaristan'da Türklere Uygulanan Asimilasyon Politikaları. Rumelide, 16, 480-498. 
Dimitrov, V. (2000). In Search of Homogeneous Nation: The Assimilation of Bulgaria's Türkish Minority, 1984-1985. JEMIE (jOURNAL Of Ethno Politics and Minority Issues in Europe) , 1-22.

Eminov, A. (1990). There Are No Turks in Bulgaria. K. H. Karpat içinde, The Turks of Bulgaria: The History, Culture and Political Fate of a Minority (s. 203-223). İstanbul: Isıs Press.

Eminov, A. (1997). Turkish and other Muslim Minorities in Bulgaria. London: Hurst\&Company.

Endişeliyiz. (1985, Ocak 27). Milliyet .

Eroğlu, H. (1992). Milletlerarası Hukuk Açısından Bulgaristan'daki Türk Azınlı̆̆ı Sorunu. Bulgaristan Türk Varhı̆ı Bildirileri (s. 15-46). Ankara: TTK.

Ersoy-Hacısalihoğulları, N. (2012). 1984-1985 İsim Değiştirme Meselesi ve Uygulamaları. 89 Göçü, Bulgaristan'da 1984-89 Azınlı Politikaları ve Türkiye'ye Zorunlu Göç (s. 171-199). içinde İstanbul: Yıldız Teknik Üniversitesi Balkan ve Karadeniz araştırmaları Merkezi (BALMED)

Ev Basıp 850 Türk'ü Öldürdüler. (1985, Şubat 7 ).Tercüman.

Evren Jivkov'dan Çözüm İstedi. (1985, Ocak 16). Cumhuriyet .

Evren ve Üruğ'a 15 bin İmzalı Dilekçe. (1985, Ocak 27). Milliyet .

Evren, Jivkov'dan Çözüm İstedi. (1985, Ocak 16). Cumhuriyet .

Gülmen, O. (2011). Bulgaristan Türkleri Tarihinden Esintiler. Ankara: İtalik Kitapları.

Hastaneler, Ölü-Yaralı Dolu, Kırktan Fazla Ölü Var. (1985, Şubat 1).Güneş .

İnönü Bulgaristan'da Durum Vahim. (1985, Ocak 29). Milliyet .

Istinata za "Văzroditelniya Protses". (2003). Istinata za "Văzroditelniya Protses",. Istinata za "Văzroditelniya Protses", Dokumenti ot Arhiva na. içinde Sofya: Institut za Izsledvane na Integratsiyata.

Karaduman: Baskıların Sürdüğü Endişesi Dağılmadı. (1985, Şubat 24). Milliyet .

Karpat, K. (2010). Etnik Yapılanma ve Göçler. İstanbul: Timaş.

Konukman, R. E. (1990). Tarihi Beldeler Işığında Büyük Göç ve Anavatan. Ankara.

Lütem, Ö. E. (2000). Türk-bulgar İlişkileri 1983-1989 Cilt 1. Ankara : ASAM.

Lütem, Ö. E. (2000). Türk-Bulgar İlişkileri 1983-1989 Cilt 1. Ankara: ASAM.

Norveç Helsinki Komitesi. (1988). Bulgaristan'daki türk ve İslam Azınlı̆̆'na Baskı. Ankara: TTK.

Özal: Değil 500 Bin, Çok Daha Fazla Soydaşımıza Kucak Açarız . (1985, Şubat 28). Cumhuriyet .

Özal: Gerekirse Kapıları Açarız. (1985, Şubat 15).Tercüman.

Özal:Bulgaristan Olaylarına Batının İlgisi Manidar. (1985, Ocak 28).Tercüman.

Öztürk, S. (2012). Devlet Hikayeleri: Kimliğin Kaybı ve Yeniden/Yenisinin Kazanılması. M. H. Neriman Ersoy-Hacısalihoğlu içinde, 89 Göçü, Bulgaristan'da 1984-89 Azınlık Politikalar ve Türkiye'ye Zorunlu Göç (s. 235-269). İstanbul: Yıldız Teknik Üniversitesi Balkan ve Karadeniz Araştırmaları Merkezi (BALMED).

Sabev, O. (2012). Osmanlı sonrası Bulgaristan'da "Yeniden Doğuş Süreçleri". M. H. Neriman ErsoyHacısalihoğlu içinde, 89. Göçü, Bulgaristan'da 1984-89 Azınlık Politikaları ve Türkiye’ye Zorunlu Göç (s. 121-137). İstanbul: BALMED.

Şimşir, B. (2012). Bulgaristan Türkleri. Ankara: Bilgi Yayınevi.

Soydaşlarımız Bulgar Zulmünü Gözyaşları İçinde Anlatıyor. (1985, Ocak 20). Tercüman.

Yalımov, İ. (2016). Bulgaristan Türk Topluluğu’nun Etno-kültürel ve Dinsel Kimliği. Sofya: Müslümanlar Diyaneti Başmüftülüğü. 